\title{
Early Permian silicified floras from the Perdasdefogu Basin (SE Sardinia): comparison and bio-chronostratigraphic correlation with the floras of the Autun Basin (Massif central, France)
}

\author{
Jean GALTIER \\ Université Montpellier 2, CNRS, UMR AMAP, \\ Montpellier, F-34000 (France) \\ jean.galtier@cirad.fr
}

Ausonio RONCHI

Department of Earth Sciences, University of Pavia,

Via Ferrata 1, I-27100 Pavia (Italy)

ausonio.ronchi@dst.unipv.it

Jean BROUTIN

Université Pierre et Marie Curie (UPMC),

UMR 7207, Centre de Recherche

sur la Paléobiodiversité et les Paléoenvironnements,

Muséum national d'Histoire naturelle,

case postale 48, 57 rue Cuvier, F-75231 Paris cedex 05 (France)

jean.broutin@snv.jussieu.fr

Galtier J., Ronchi A. \& Broutin J. 2011. - Early Permian silicified floras from the Perdasdefogu Basin (SE Sardinia): comparison and bio-chronostratigraphic correlation with the floras of the Autun Basin (Massif central, France). Geodiversitas 33 (1): 43-69. DOI: 10.5252/g2011n1a4.

\begin{abstract}
In the Perdasdefogu Basin (Ogliastra, Sardinia) plants occurring in angular cherts are preserved as siliceous permineralizations. The plant assemblage consists of the genera Sphenophyllum, Arthropitys, Astromyelon, Palaeostachya, Pecopteris, Scolecopteris, Stewartiopteris, Psaronius, Ankyropteris, Anachoropteris; furthermore, probable medullosan wood and ovules, cordaitean stems, leaves and ovules, and Dadoxylon wood have been recorded. Arborescent marratialean ferns are the dominant elements with Pecopteris and Scolecopteris leaves being the most common; the calamiteans are the second in abundance. Generally the chert blocks contain a large number of plant fragments - roots and leaves are being almost equally represented - suggestive of a coal ball-like plant accumulation. More rarely a chert block may consist of a single plant part, for example a piece of wood. The preservation and accumulation of the plants are closely comparable to the silicified plant assemblages described from the Lower Permian of Autun and the upper Pennsylvanian of Grand-Croix (Massif central, France) and from the Early Permian Döhlen Basin (Germany).
\end{abstract}




\author{
KEY WORDS \\ Silicified floras, \\ Autunian, \\ Early Permian, \\ Sardinia, \\ compression macrofloras.
}

It is certainly significant that the assemblage from the Perdasdefogu Basin is dominated by tree ferns and calamites like the coeval silicified vegetation from Autun. However, like in Autun, the permineralized flora contrasts with the underlying compression floras dominated by conifers and peltasperms. The Perdasdefogu macroflora record suggest a middle-upper Autunian age which corresponds to the Surmoulin and Millery formations of the Autun Basin. This is in agreement with the Asselian-Sakmarian transition as pointed out by the amphibian species found in the same formation, and perfectly correlatable with the same association found in Gottlob-lake (Thuringian Forest Basin). Because of its rich fossil content, the Perdasdefogu Basin represents a reference succession for the Autunian of the entire westernmost palaeo-Tethyan domain and its macrofloral record.

\section{RÉSUMÉ}

Flores silicifiées du Permien basal du Bassin de Perdasdefogu (SE de la Sardaigne): comparaison et corrélation bio-chronostratigraphique avec les flores du Bassin d'Autun (Massif central, France).

Dans le Bassin de Perdasdefogu (Ogliastra, Sardaigne) des cherts anguleux renferment des plantes préservées sous forme de perminéralisations siliceuses. Lassemblage comprend les genres Sphenophyllum, Arthropitys, Palaeostachya, Pecopteris, Scolecopteris, Stewartiopteris, Psaronius, Ankyropteris, Anachoropteris, du bois et des ovules appartenant probablement à des Médullosales, des tiges, feuilles et ovules de type cordaitales et, rarement, du bois de Dadoxylon. Les fougères arborescentes marratiales constituent l'élément dominant avec les feuillages Pecopteris et Scolecopteris comme fossiles les plus communs; les sphénopsides calamitales sont deuxième en abondance. Généralement un spécimen de chert contient un grand nombre de fragments végétaux (racines et feuilles presque à égalité) suggestif d'une accumulation végétale de type coal-ball. Plus rarement un spécimen peut correspondre à un seul fragment, par exemple un morceau de bois. La préservation et l'accumulation des végétaux sont très comparables à ceux des assemblages de plantes silicifiées du Permien basal d'Autun et du Pennsylvanien de Grand-Croix (Massif central, France) ainsi que du Bassin Permien basal de Döhlen (Allemagne). Il est certainement significatif que l'assemblage provenant du Bassin de Perdasdefogu soit, comme la végétation silicifiée contemporaine d'Autun, dominé par les fougères arborescentes et les calamitales. Cependant, comme à Autun, la flore perminéralisée contraste avec les flores en compression sous-jacentes qui sont caractérisées par la présence de coniferres et de peltaspermes. L'inventaire de la macroflore de Perdasdefogu suggère une datation Autunien moyen-supérieur qui correspond précisément aux formations de Surmoulin/Millery du Bassin d'Autun. Ceci est conforme avec un intervalle de temps à la transition Asselien-Sakmarien, ainsi que le suggère la présence d'amphibiens dans des intervalles stratigraphiques très voisins et parfaitement corrélables avec la même association trouvée au lac Gottlob (Bassin Thuringian Forest). L'analyse comparée des horizons silicifiés fossilifères, bien repérés dans la succession stratigraphique de Perdasdefogu et de ceux provenant des formations de Surmoulin et Millery dans le Bassin d'Autun, suggère qu'ils sont contemporains et d'âge Permian basal. Compte-tenu de son riche contenu fossilifere, le Bassin de Perdasdefogu représente indiscutablement une succession de référence pour l'Autunien dans l'ensemble le plus occidental du domaine paléo-téthysien et pour sa macroflore. 


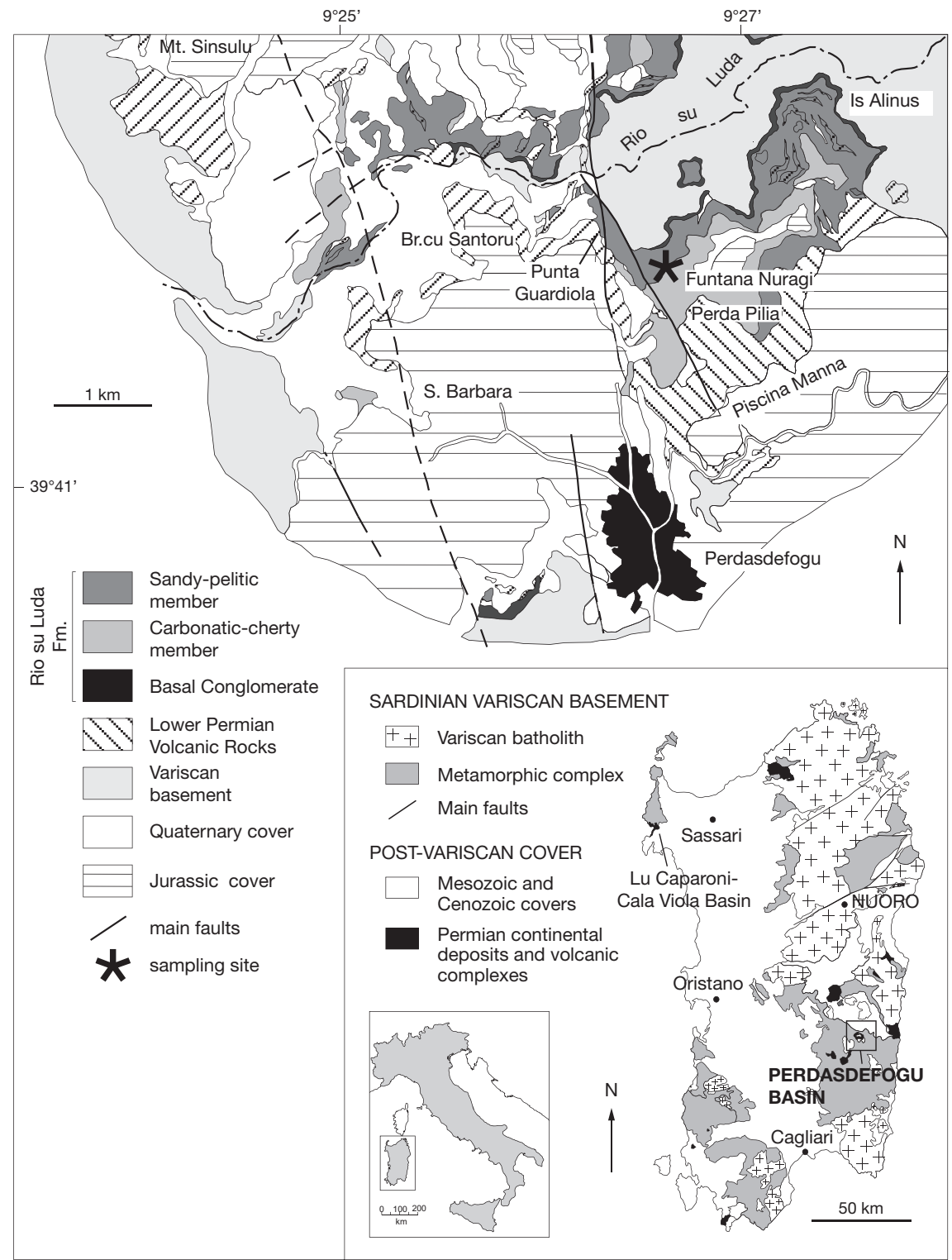

FIG. 1. - Location of silicified floras from the Perdasdefogu Basin (Ogliastra, Sardinia): A, Sardinia simplified geological map with position of the major Late Carboniferous-Permian basins; B, Southern portion of Perdasdefogu Basin with the site of discovery of permineralized plants.

\section{INTRODUCTION}

Small intramontane basins, formed in Sardinia at the end of the Variscan Orogeny, have been filled up with volcano-sedimentary deposits very rich in fossils and attributed to a Late CarboniferousEarly Permian age, based mainly on compression macrofloras (Arcangeli 1901; Comaschi Caria 1959). Some of these basins (Perdasdefogu, Escalaplano, Mulargia, Seui-Seulo, Lu Caparoni) 
have been recently reinvestigated in great detail (Ronchi 1997; Ronchi et al. 1998, 2008; Broutin et al. 2000a, b; Cassinis et al. 2000; Freytet et al. 2002; Werneburg et al. 2007). Some of them, such as the Perdasdefogu Basin, yielded new, diverse palaeontological contents (algae, stromatolites, ostracods, bivalves, gastropods, amphibians and fish remains) that allowed dating these sediments as Asselian-Sakmarian (Ronchi et al. 1998, 2008; Werneburg et al. 2007). A rich and very well preserved silicified flora was also found in the Perdasdefogu Basin during the $\mathrm{PhD}$ research of one of us (AR). These plants were found especially in the Funtana Nuragi locality in the upper silicified horizons of the "black limestones" or lithozone d of the Rio su Luda Formation (Ronchi \& Falorni 2004) and have been first mentioned and briefly described in Ronchi et al. (1998) and in Broutin et al. (1999; 2000b). The objectives of the present paper are: 1) to describe and illustrate, for the first time in detail, the silicified plant assemblage from Perdasdefogu; 2) to compare it with other contemporaneous European permineralized floras; and 3) to discuss its palaeoecological and palaeogeographical significance with regard to the associated compression macrofloras.

\section{MATERIAL AND METHODS}

\section{GeOlogical SETTING}

The Lower Permian Perdasdefogu Basin extends for about $25 \mathrm{~km}^{2}$ in the Ogliastra region (central to southeastern Sardinia, Fig. 1A) and is located north of the homonymous village (Fig. 1B). Before a drilling campaign of Pro.Ge.Mi.Sa company (Sarria 1987) and the renewed interest of a multidisciplinary group of researchers (see e.g., Broutin et al. 1996; Ronchi et al. 1998, 2008; Cassinis et al. 2000; Pertusati et al. 2002; Werneburg et al. 2007), very few and mostly older studies have dealt with its palaeontologic-stratigraphic content (e.g., Maxia 1938; Fois 1939). In the second half of the 1990s, these studies were coupled with detailed mappings of the area for the 1:50 000 geological maps of the Italian Geological Service (CARG project; Pertusati et al. 2002a, b).
Very similarly to other small late Palaeozoic continental troughs in Sardinia (e.g., EscalaplanoMulargia, Seui-Seulo), the Perdasdefogu Basin is an internally-drained post-Variscan palaeograben. Drillings have revealed an asymmetrical half-graben structure, controlled by a major normal fault, tilted blocks and by transverse structures. Strike-slip tectonic activity along the fault systems caused the tilting and sinking of basement blocks, giving rise to a pull-apart graben, presently elongated NW-SE, most of which is now covered by Jurassic carbonaceous platform sediments. This Lower Permian basin originated in response to post-orogenic transtensile tectonic conditions, broadly similar also to those of many other basins of continental Paleoeurope active from the Late Carboniferous to the Early Permian (e.g., Arthaud \& Matte 1977; Cassinis 1996; Ziegler \& Stampfli 2001; Virgili et al. 2006).

The Permian sedimentary and volcanic units are exposed with variable lateral extension and thickness related to the palaeomorphology of the basin and tectonic movements. The best exposures are on both sides of the incised valleys of rivers (Rio) Su Luda and (Rio) Flumineddu and to the north of the Jurassic dolostone covers called Tacco (i.e. Plateau) de Giuncus-Monte Perdalonga.

\section{STRATIGRAPHIC FRAMEWORK}

The Perdasdefogu Basin is characterized by a sequence about $250 \mathrm{~m}$ thick in which the strictly sedimentary units are frequently intercalated with and overlain by different magmatic units (Figs 2; 3).

The over $150 \mathrm{~m}$ thick siliciclastic/calcareous fluviolacustrine sedimentary sequence is represented by the Rio Su Luda Formation (Pertusati et al. 2002a, b; Ronchi \& Falorni 2004). In the Perdasdefogu Basin, this formation is composed of the stacking of three main lithofacies: it begins with a polygenic basal conglomerate (formally lithofacies $a$, maximum $30 \mathrm{~m}$ thick), that bears rock fragments derived from the Variscan metamorphic basement. This first sedimentary unit, locally reddish-violet to grey-greenish, evolves from a lower lithofacies with coarse-to-fine conglomerates to an upper one, composed of microconglomerates to coarse-grained sandstones up to mudstones with even and cross-bedding. The boundary with the basement is marked by a pronounced unconformity. 


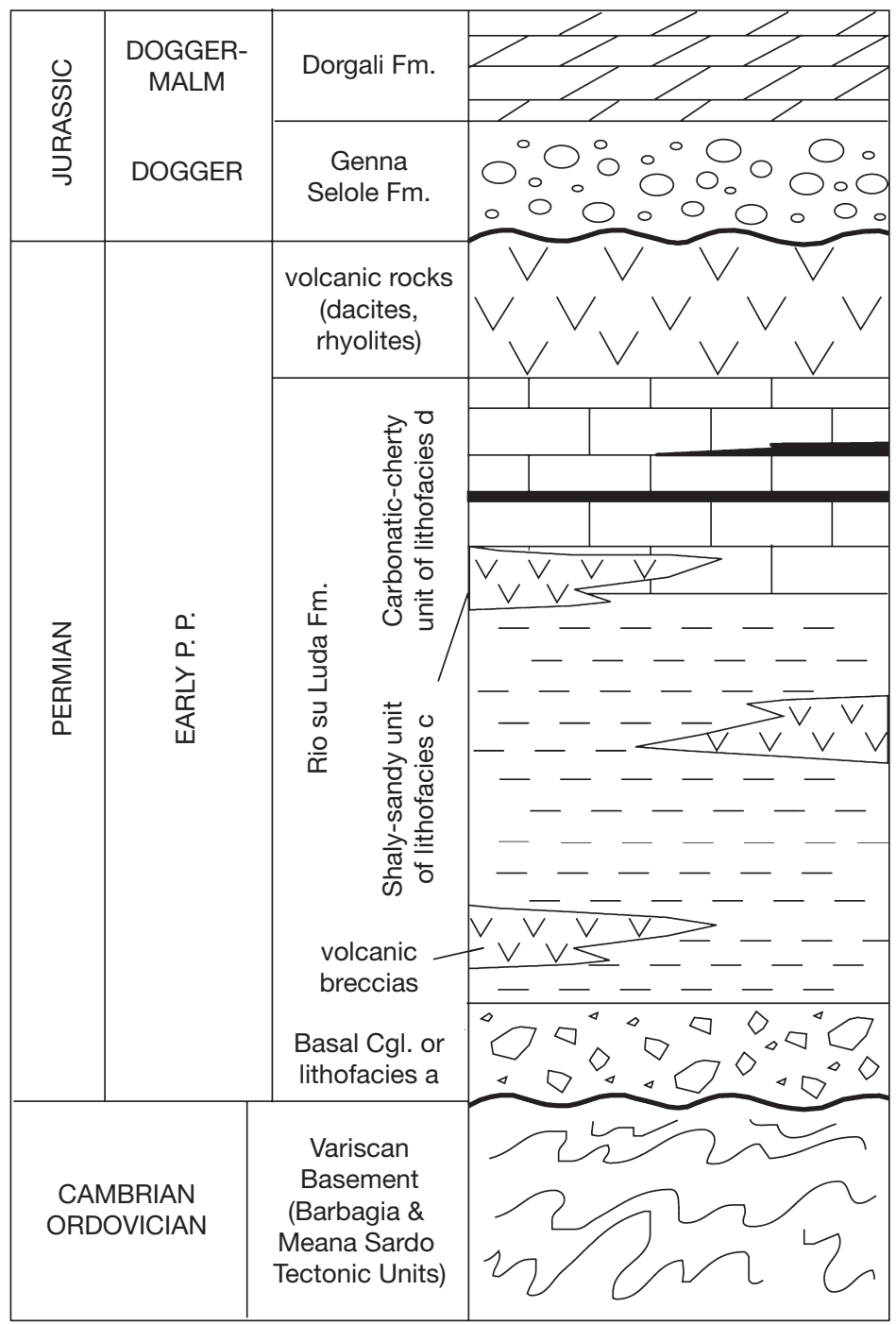

FIG. 2. - Schematic stratigraphic column of the Lower Permian continental deposits in the Perdasdefogu Basin, Sardinia.

Above this first coarse sedimentary unit, a fluvialto-lacustrine lithofacies $c$, the "black siltstones" ("unità siltoso-arenacea" of Ronchi [1997] and Ronchi \& Sarria in Cassinis et al. 2000), locally exceeding a thickness of $120 \mathrm{~m}$, crops out. It consists of dark-grey laminated sandstones, siltstones and shales, associated with more or less consistent conglomeratic intervals and calcalkaline intermediate volcanoclastic breccias and lava products showing vertical and lateral variations in thickness.

The upper unit (lithofacies $d$, up to $70 \mathrm{~m}$ thick), the "black limestone" ("unità calcareo-selciosa" of Ronchi 1997), is composed of lacustrine darkgrey to blackish laminated limestones and dolostones, with frequent fine sandstones to laminated mudstones. Black bedded chert intercalations of volcanic origin occur at different levels and 
hyaloclastites-cinerites, representing completely devetrified pomiceous tuff and ash-fall deposits flowed into lacustrine waters appear particularly at its top. In addition, in the lacustrine carbonate beds subordinate anthracitic layers (max. 1.25 $\mathrm{m}$ thick) occur medium to fine, as well as thin, conglomerate beds. The presence of cubic pyrite crystals, often inside rounded nodules that are some centimetres in diameter, is consistent with highly reducing environments and by dysoxic conditions at the bottom of the lake. At the top of this lithofacies some tens of meters of coarseto-fine pyroclastic fall deposits, that are more or less silicified, can occur locally.

The finer laminated sediments and the carbonate layers are referred to a very shallow lacustrine environment.

The early volcanic record in the Perdasdefogu Basin, above the basal conglomerate, is in the SSE area (Perda Pilia) mostly represented by intermediate volcanic breccias that occur in variable thicknesses $(0-50 \mathrm{~m})$, interbedded within the pelitic-siltitic lower unit and also laterally occurring in the upper carbonatic unit. These latter sediments are overlain by a widespread dacitic lava flow (Bruncu Santoru high), calc-alkaline in composition, with a thickness that reaches up to a maximum of $180 \mathrm{~m}$. However, in the northwestern sector of the basin, these dacitic rocks are associated with or are followed by rhyolitic volcaniclastic sediments, mostly tuffs and ignimbrites, which are also calc-alkaline in composition. Dacitic and rhyolitic dikes linked to this younger volcanic activity, can also sparsely be observed in the basinal area, crossing the Variscan crystalline complex and the overlying units already described (Cassinis et al. 1998; Cortesogno \& Gaggero in Cassinis et al. 2000).

Black, silicified decimetric beds of reworked fine-grained vitroclastic materials are widespread in the upper unit; the black colour of these levels is related to the inclusion of abundant plant material. K/Ar (WR) radiometric datings performed on the "quartz-latitic lavas" of Bruncu SantoruGianni Vuddu were very likely affected by thermal alteration processes, because they yielded ages of $220 \pm 5$ and $218 \pm 6 \mathrm{My}$, which are not in agree- ment with the local stratigraphy (Lombardi et al. 1974). These deposits are overlain with an angular unconformity by very coarse-grained quartz conglomerates and/or dolostones (respectively "Formazione di Genna Selole" and "Dolomie di Dorgali"); these have been so far ascribed to the Middle Jurassic (Dogger).

The Perdasdefogu permineralized flora was found in the southeastern part of the basin (Funtana Nuragi-Ortu Mannu localities) within stratified limestone layers of the Rio su Luda Formation ("black limestones" member or lithofacies d), which also show silicification phenomena. The resulted lithology is represented by black cherts. A complete and detailed stratigraphic section could not be established in this area due to the presence of a large intermediate volcanic to volcaniclastic body (mainly located in Perda Pilia area), which partially disrupts the sedimentary sequence and makes the local geology complicated. For reference, a section (Punta Guardiola) measured a few hundred metres west of the fossil locality is shown in Figure 3.

The Perda Pilia volcaniclastic unit, deposited in a sub-aerial swampy setting, is very likely responsible for the heavy silica input which saturated the waters where the vegetation was accumulating.

\section{MeTHODS}

The plants occur in angular cherts; they are preserved as siliceous permineralizations showing various degrees of cell wall preservation. When the organic matter is preserved the plant fragments are dark brown and the peel section method, with HF etching (Galtier \& Phillips 1999), has been used. However, when the residual carbon has been lost the plants are of light colour, and thin petrographic sections must be prepared. More than 70 chert blocks have been sectioned and cellulose acetate peels were prepared from all the surfaces. For each specimen the taxa and the types of organs, which are present, have been identified. This represents a total of many hundreds plant fragments that provide a preliminary indication of the relative occurrence of plants and organs in the assemblage. The silicified plant material, prefixed by SAR, is kept in the AMAP Research Unit (collections de Paléobotanique, Université Montpellier 2). 


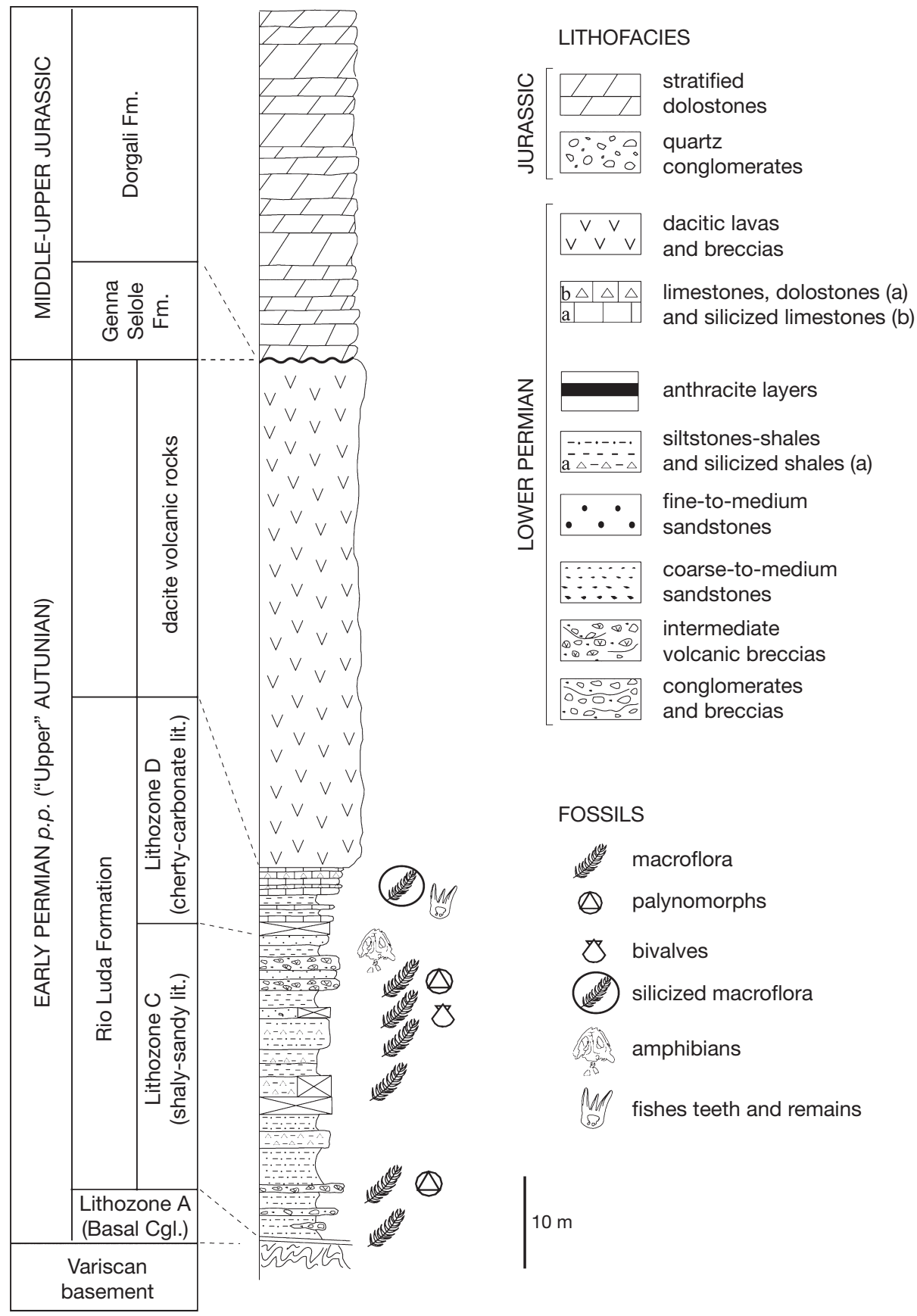

FIG. 3. - The Punta Guardiola reference section, some hundreds of metres west of Funtana Nuragi, Sardinia. 


\section{COMPOSITION OF THE FLORA AND SYSTEMATICS}

Generally, each chert block contains an accumulation of plant fragments (mainly roots and leaves) with frequent occurrences of coprolites of very different sizes. This is suggestive of coal ball-like plant accumulations, therefore, the plant assemblage may be interpreted as a litter. However in some cases a specimen consists of a single woody plant fragment.

\section{LYCOPSIDS}

Stigmarian rootlets occur rarely, associated with calamitean roots; they are the only known representative of lycopsids and certainly belonged to sigillarian plants not yet discovered.

\section{SPHENOPSIDS}

In contrast to lycopsids, the calamiteans are very important elements of the plant assemblage.

\section{Arthropitys cf. renaultii Boureau, 1964}

(Fig. 4A, E)

This small stem, about $3 \mathrm{~mm}$ in diameter, shows an excellent preservation of the tissues. There are 17 primary xylem strands, with circular carinal canals, surrounding the pith (see detail on Figure $4 \mathrm{E}$ ). The absence of any secondary xylem supports its interpretation as a very young twig. Other examples of similar small stems have been found with leaves attached. These stems are referred with some reservations, to $A$. renaultii Boureau, 1964 from the Lower Permian of Autun that represents a similar young stem devoid of secondary xylem, but with a larger number (34) of primary xylem strands and with a proportionally narrower cortex. In the present specimen the outer cortex is sclerenchymatous with alternating parenchyma (arrow, Fig. 4E) but the inner cortex shows larger cells (C, Fig. 4E).

\section{Arthropitys bistriata \\ (Cotta) Goeppert, 1864}

(Fig. 4B-D, F, G)

We attribute a number of stems showing a wide range of sizes and of secondary xylem thickness to this species. The small stem (Fig. 4B) has a diameter of $19 \times 5 \mathrm{~mm}$ including the cortex; it shows a small development of secondary xylem $(0.5 \mathrm{~mm}$ thick, i.e. about 15 tracheids); 62 primary xylem strands with carinal canals $(80 \mu \mathrm{m}$ in diameter) are surrounding the pith at $0.7 \mathrm{~mm}$ intervals (Fig. 4F). Secondary xylem wedges are separated by interfascicular rays that are 5-6 cells wide. The outer sclerenchymatous cortex is well preserved as well as groups of large cells in the inner cortex (arrow, Fig. 4F). This young stem shows the beginning of development of secondary xylem. In its general organization, small amount of secondary xylem and cortex anatomy, it is very similar to specimens of $A$. bistriata var. augustodunensis from Autun illustrated by Renault (1893: pl. 46, fig. 7; pl. 47, figs 1, 2).

Other observed specimens belonged to older parts of plants, with a wood thickness ranging from 1 to $60 \mathrm{~mm}$, but generally the cortex is missing. For example the stem (Fig. 4C) has a wood of $10 \mathrm{~mm}$ thick; it represents probably one third of the original woody cylinder. About 30 primary xylem strands are visible; carinal canals are 100 to $250 \mu \mathrm{m}$ in diameter, their preservation may be excellent (Fig. 4G) and sometimes there is no lacuna (arrow, Fig. 4C). The average distance between carinal canals is $1 \mathrm{~mm}$, it may be up to $2 \mathrm{~mm}$ in stems with wood several centimetres thick. In transverse section, interfascicular rays are less than $1 \mathrm{~mm}$ wide, made of 5 to 8 parenchymatous cells, and they are generally visible through the whole secondary xylem. The secondary xylem wedges consist of rays and tracheids showing an initial quick increase of their diameter from 30 to $70 \mu \mathrm{m}$ (Figs 4F, G). Some specimens consist of a single fragment of wood including a portion of the pith and a few primary xylem strands. The observed maximum wood thickness of $60 \mathrm{~mm}$ suggests an

FIG. 4. - Silicified plants from the Permian of Sardinia: A, E, Arthropitys cf. renaultii Boureau; A, transverse section of a young twig (SAR01B1B01); E, detail of the same showing the pith, primary xylem strands with carinal canals and well preserved cortex with large cells (C) in inner cortex and alternating bands of sclerenchyma and parenchyma in outer cortex (arrow); B-D, F, G, Arthropitys bistriata 


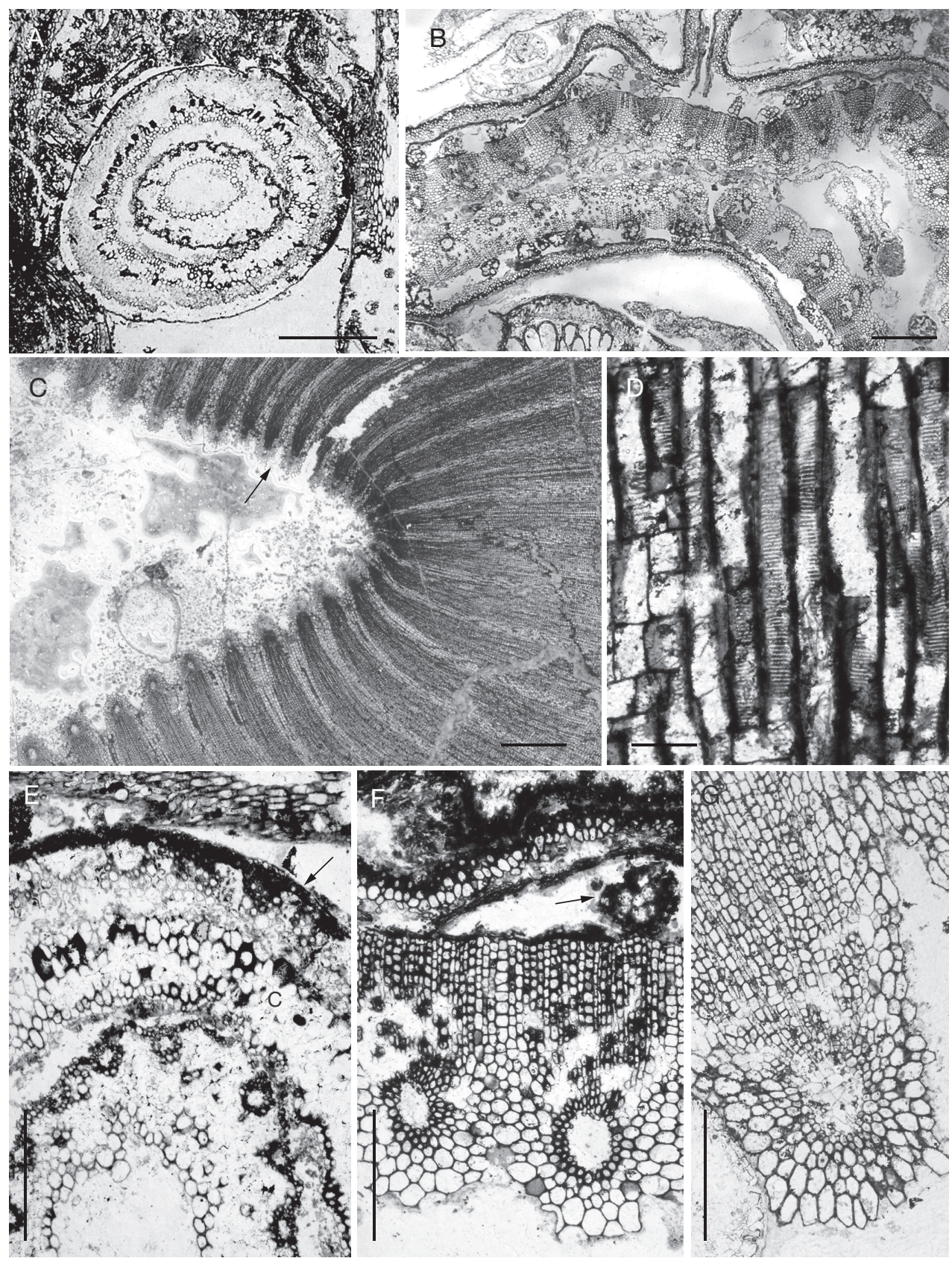

(Cotta) Goeppert; B, incomplete transverse section of a young stem showing a little development of secondary xylem (SAR40C1T03); C, partial transverse section of an older stem with thick secondary xylem and well-marked interfasciculary rays (SAR58C1B01); D, radial longitudinal section in the secondary xylem showing scalariform pitting of tracheids and high ray cells on the left (SAR51BL01); $\mathbf{F}$, detail of the stem (B) showing two primary xylem strands with circular carinal canals, one interfascicular ray, small development of secondary xylem, cluster of large cells (arrow) in inner cortex and sclerenchymatous outer cortex; $\mathbf{G}$, detail of one primary xylem strand and secondary xylem wedge of a stem with thick wood (SAR51A01). Scale bars: A-C, $1 \mathrm{~mm}$; E-G, $0.5 \mathrm{~mm}$; D, $100 \mu \mathrm{m}$. 
original stem diameter of at least $15 \mathrm{~cm}$ if we include the pith and cortex. This corresponds to some specimens of $A$. bistriata illustrated by Renault (1893: pl. 44 , figs 1,2 ) as well as original specimens of the species described by Cotta (1832). In all the observed stems the secondary xylem tracheids show scalariform thickening to pitting on their radial walls (Fig. 4D). All the features recognized in these specimens suggest that they belong to Arthropitys bistriata. However, the original material of this species was decorticated and Cotta's diagnosis did not include cortical features or information on young stems such as that presented by Renault (1893-1896) for $A$. bistriata var. augustodunensis. There is also a strong presumption that the very small stems attributed to $A$. renaultii belong to the same plant. Detailed comparison of this material is out of the scope of the present paper.

\section{Palaeostachya sp. \\ (Fig. 5A-E)}

Small cones 2-4 mm long and up to $10 \mathrm{~mm}$ in diameter are relatively common elements of the assemblage. They show whorls of 24 or 28 separate sterile bracts at each node, one half of the bract subtend the 12 or 14 axillary sporangiophores (Fig. 5B). In cross section the cone axis is broadly circular (3-5 $\mathrm{mm}$ in diameter) with a pith cavity and 12 or 14 primary xylem bundles with a carinal canal (Fig. 5C). There is a discontinuous narrow zone of secondary xylem and, at the node level, lacunae are present in the cortex of the cone axis, immediately outside the secondary xylem. In most specimens the bracts are broken at their point of attachment to the cone axis (Fig. 5A [B]); they extend perpendicularly outwards for a short distance before ascending vertically for about 10 $\mathrm{mm}$, i.e. a little more than two nodes (Fig. 5A); this is confirmed by transverse sections showing two or three whorls of bracts (Fig. 5A [B]). The measured length of the internodes is 3.7 to $4 \mathrm{~mm}$. Individual bracts show a maximum tangential diameter $(1 \mathrm{~mm})$ in the ascending lamina. The sporangiophore stalks arise obliquely from the base of the bracts (Fig. 5A [ST]), a characteristic feature of Palaeostachya cones. Sporangiophores are borne by two contiguous (fertile) bracts alternating with two sterile ones. The stalks are narrow $(0.3 \times 0.4$ $\mathrm{mm}$ in diameter), losangic in transverse section with a sclerenchym with a sclerenchymatous black cortex efficient for mechanical support of the sporangia (arrows on Fig. 5D). The sporangiophores are peltate (Fig. $5 \mathrm{C}[\mathrm{P}]$ ), each bearing 4 sporangia. Nearly all the sporangia (Fig. 5A-C [S]) are dehiscent and distorted, however, we can estimate their length to $2 \mathrm{~mm}$ and their diameter to $1 \mathrm{~mm}$. The peltate sporangiophore head (Fig. $5 \mathrm{C}[\mathrm{P}]$ ) is about $2 \mathrm{~mm}$ broad and parenchymatous tissue extends at the base of each sporangium. Spores are rarely preserved, spherical, about $100 \mu \mathrm{m}$ in diameter (arrows, Fig. 5E).

In their general organization these cones are similar to those of Palaeostachya andrewsii (Baxter, 1954) from Pennsylvanian coal balls of Iowa based on an exceptionally preserved specimen allowing to recognize features not completely available in our material; in addition, the spores of the American cone are larger. A detailed study is necessary to decide of the taxonomic attribution of the present specimens which can also be compared to Palaeostachya (Volkmannia) gracilis cones described by Renault (1876; 1896) from the Lower Permian of Autun. One of us (JG) recently re-investigated Renault's material and recognized strong similarities, but the cones from Autun correspond to several taxa, generally of larger size, with the exception of one specimen described as "Volkmannia" sp. (Renault 1896).

\section{Astromyelon sp.}

(Fig. 5F)

We will designate under this name the calamitean roots and rootlets which represent one of the most common elements of the plant assemblage, and

FIG. 5. - Silicified plants from the Permian of Sardinia: A-E, Palaeostachya sp.: A, longitudinal section of the cone showing the central axis with pith cavity (A) and three nodes with the attachment of bracts (B) and sporangiophore stalks (ST) arising obliquely. The bracts are often displaced at their base (B with two arrows) whilst their distal part is ascending vertically (see on the left) (S), de- 

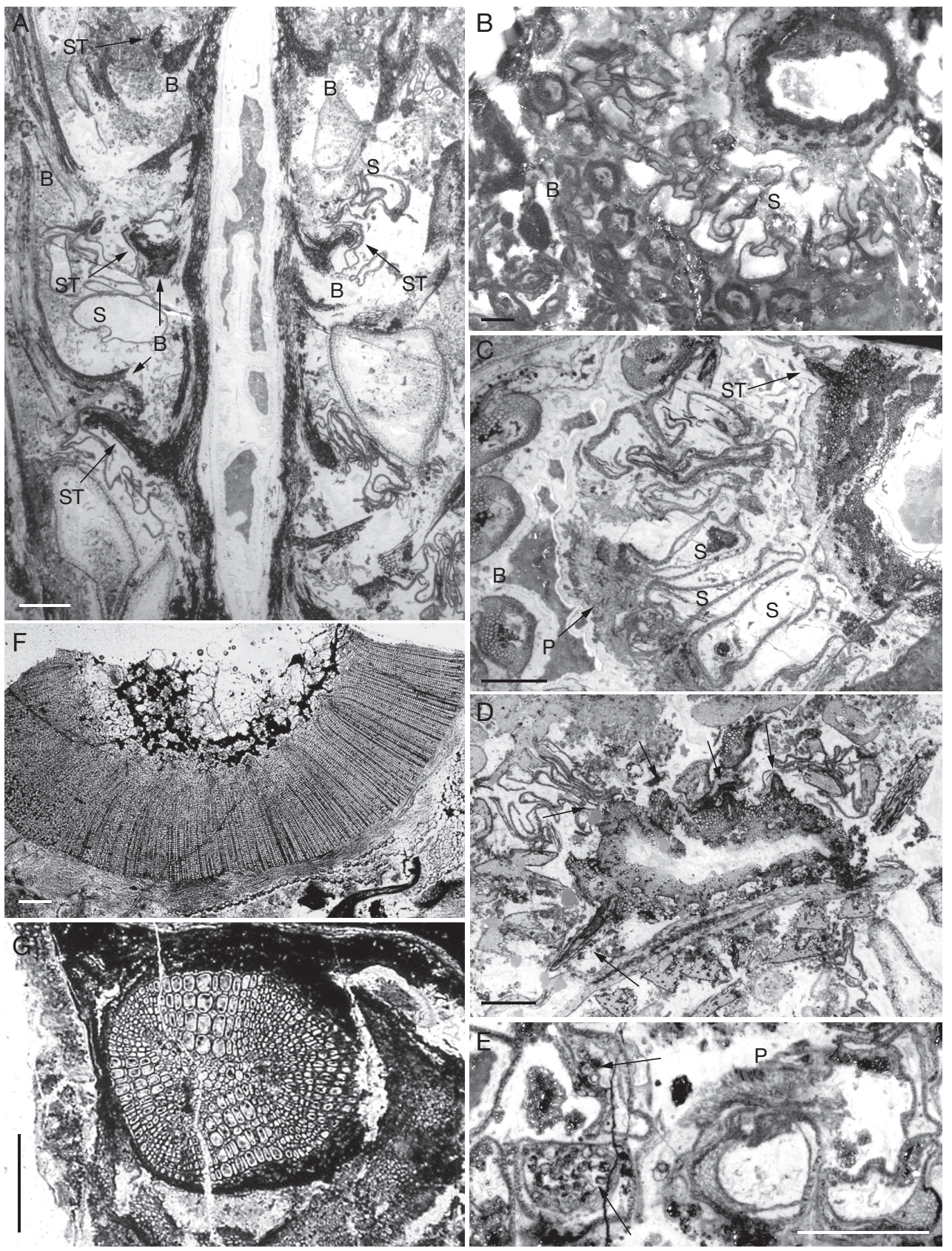

hiscent sporangia with folded wall) (SAR45A2L08); B-D, transverse sections of cones; $\mathbf{B}$, part of one section showing the cone axis (upper right) surrounded by whorls of sporangia (S) and bracts (B) (SAR63A01); C, detail of a similar section showing the cone axis, at right, the base of one sporangiophore stalk (ST), sporangia in oblique-longitudinal section (S), two of them being attached to the sporangiophore peltate head (P) and distal lamina of bracts (B) at left (SAR01B3L13); D, distorted cone axis showing the attachement of several sporangiophore stalks (arrows) (SAR45BB04); $\mathbf{E}$, detail of transverse sections of sporangia, one shows attachment to the sporangiophore peltate head (P), the two on the left contain spores (arrows) (SAR01B1BO3); F, Astromyelon sp., transverse section of a large decorticated root (SAR43CT01); G, Sphenophyllum sp., transverse section of a stem (SAR33C01). Scale bars: $1 \mathrm{~mm}$. 

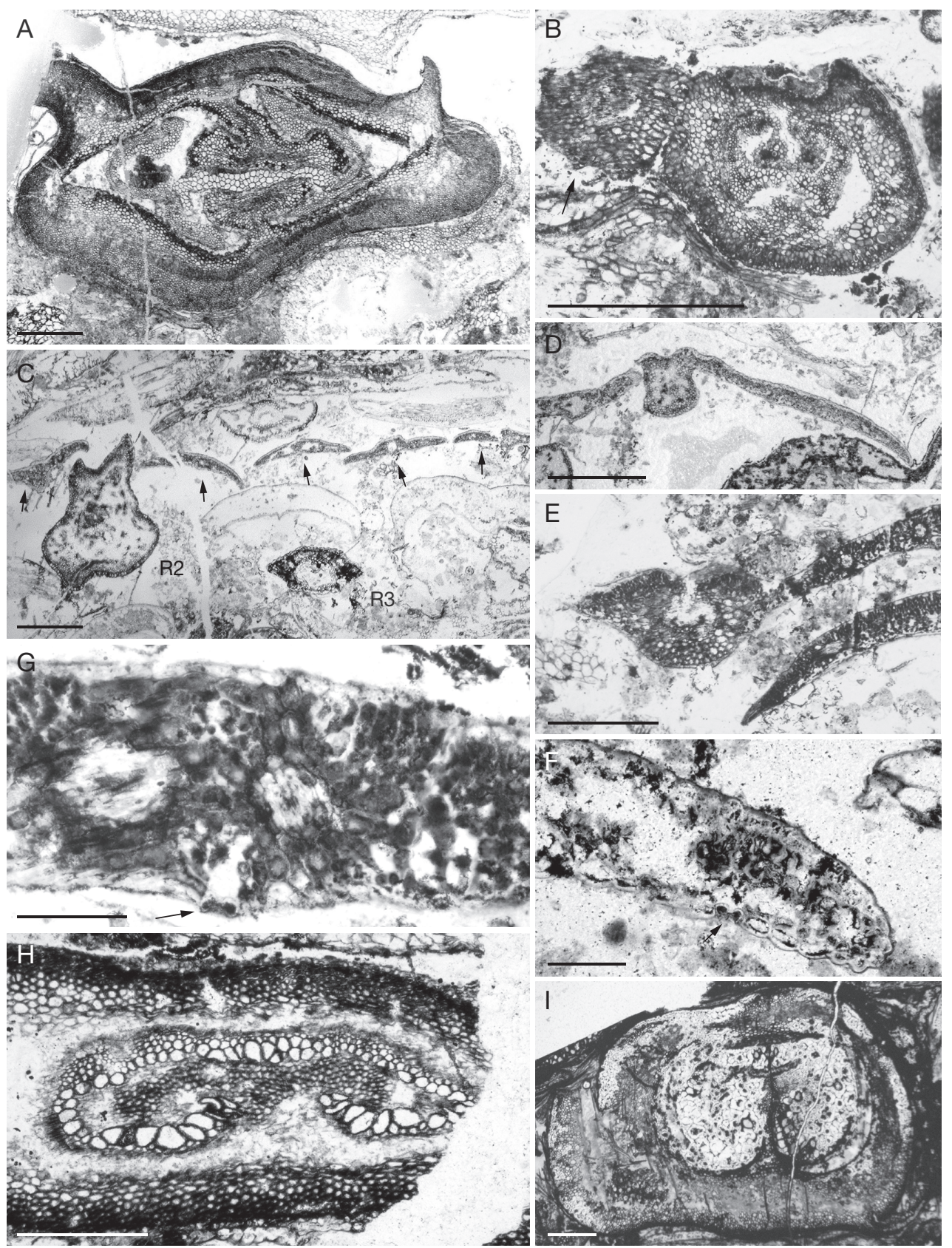

FIG. 6. - Silicified plants from the Permian of Sardinia: A-G, Ankyropteris brongniartii Renault, transverse sections of rachises and pinnules, all oriented with adaxial surface upwards: A, primary rachis (SAR01B1B03); B, secondary rachis with the base of a third order one (arrow) (SAR11AS01); C, connected rachises of second (R2) and third order (R3) with pinnules (arrows) (SAR01B1B02); D, third order or ultimate rachis with attached pinnules (SAR01A1B02); $\mathrm{E}$, another ultimate rachis sowing the $\mathrm{C}$-shaped xylem strand and attached pinnules (SAR11AS01); $\mathbf{F}, \mathbf{G}$, sections of pinnule lamina showing stomata (arrows), thick epidermis on both faces and veinlets in G (SAR01B1B01, SAR11AS01); H-I, Anachoropteris pulchra Corda, transverse sections of probable second order rachis $(\mathbf{H})$ and large primary rachis (I) showing abaxially enrolled xylem strand (SAR08BB03, SAR24B02). Scale bars: A-D, I, 1 mm; E, H, 0.5 mm; F, G, 100 m. 

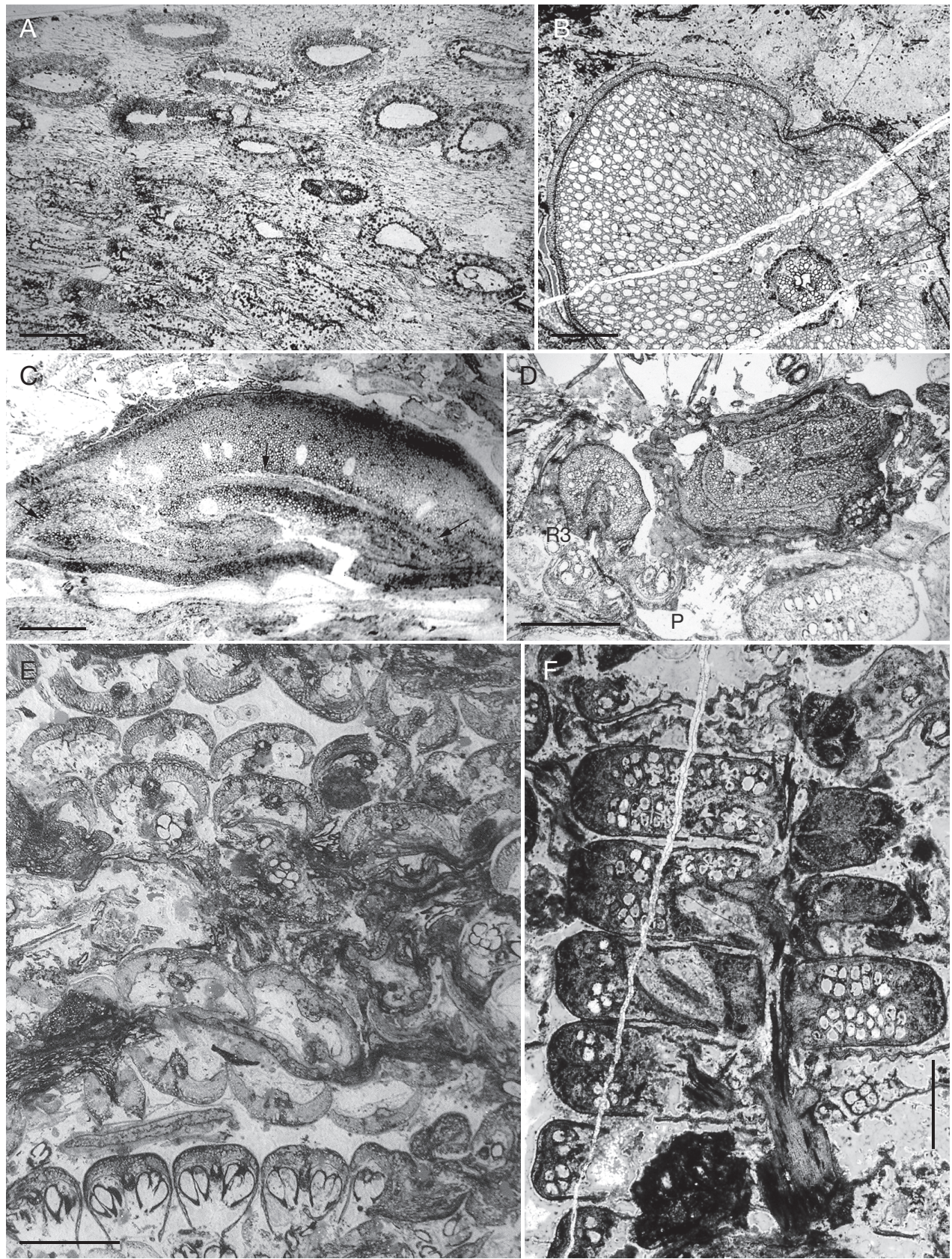

FIG. 7. - Silicified plants from the Permian of Sardinia: A, B, Psaronius sp.; A, part of the inner root mantle of a trunk, transverse section showing the small roots and interstitial tissue (SAR 13BB01); B, transverse section of one large free root of the outer zone; note the broad aerenchymatous cortex (SAR10A01); C, D, rachises of fronds borne by Psaronius; C, Stewartiopteris sp.1, rachis with a broad C-shaped xylem strand (arrows) and middle cortex with small lacunae (SAR59AT01); D, Stewartiopteris sp. 2., rachis with a different cortex bearing a probable third order one (R3) with fertile pinnule attached (SAR46B01); E, F, foliage of fronds borne by Psaronius; E, accumulation of fronds showing vegetative (above) and fertile pinnules (below) seen in transverse section (SAR40C1T01); F, part of a fertile pinna seen in paradermal section (SAR03A1T02). Scale bars: $2 \mathrm{~mm}$. 
probably the most important in terms of volume. We illustrate one rather broad but decorticated woody root (Fig. 5F). Smaller roots (less than $1 \mathrm{~cm}$ in diameter) with a little or no secondary xylem have generally a lacunose cortex preserved and are assignable to the genus Myriophylloides. Similar roots are present in the Autun material, however, $A$. augustodunense Renault, 1896 and $A$. reticulatum Renault 1896 differ in detail of their cortex and correspond to rather large roots like the one illustrated here of which cortical features are missing.

\section{Sphenophyllum sp.}

(Fig. 5G)

We only found two specimens of these small stems, partly decorticated but showing well-developed secondary xylem. There is no diagnostic feature allowing a specific identification. This genus extends up to the Early Permian where it has been found preserved as compressions at Autun (Igornay).

\section{FERNS}

Ferns, particularly marratialean tree ferns, are the most common element of the flora.

Ankyropteris brongniartii Renault, 1869

(Fig. 6A-G)

This small tedelean fern is one of the best known Palaeozoic ferns (Phillips \& Galtier in press); it has a wide stratigraphic range from Early Pennsylvanian to Early Permian where it was first described from Autun by Renault (1869) and from Chemnitz by Stenzel (1889) under the name Ankyropteris scandens. This fern is a vine known to have been growing on trunks of the Psaronius tree ferns. We found portions of all the different parts of the tripinnate frond in a few specimens. The primary rachis (Fig. 6A) has the characteristic $\mathrm{H}$-shaped xylem strand, and a secondary rachis with the base of third order one is illustrated on Figure 6B. Foliage of this fern was found lying gently within accumulations of leaves of other plants (Fig. 6C). Tertiary rachises (R3, Fig. 6C-E) and pinnules have been observed. Their excellent preservation reveals unknown details on the anatomy of the rather rigid pinnules (Fig. 6C-G). Their lamina proves to be significantly thicker than in the rare examples previously described from Pennsylvanian material; the histology of the mesophyll is revealed as well as the occurrence of stomata (arrows, Fig. 6F, G). Unfortunately fertile pinnae have not been found.

\section{Anachoropteris pulchra Corda, 1845}

(Fig. 6H, I)

A few fragments of rachises of this fern have been found; one (Fig. $6 \mathrm{H}$ ) shows the characteristic abaxially enrolled xylem strand, a feature more hardly visible in another specimen (Fig. 6I). The latter is a larger rachis with a still more inrolled xylem strand. Both are conform to the species Anachoropteris pulchra Corda from Radnice, also recognized at Grand-Croix and Autun (Corsin 1937).

Marattialean tree ferns: fragments of the different parts of the plant are present in nearly $90 \%$ of the specimens including Psaronius trunks with aerial roots, Stewartiopteris petioles and rachises, Pecopteris and Scolecopteris pinnules

\section{Psaronius sp.}

(Fig. 7A, B)

Fragments of root mantle of Psaronius trunks are common elements; they occur in about half of the specimens either as portions of the inner root mantle (Fig. 7A) where the roots are cohesive with an interstitial tissue, or as isolated larger roots from the outer zone of the trunk (Fig. 7B) showing a characteristic aerenchymatous cortex and stellate xylem strand. In the absence of information on the stele of the stem a specific attribution is, however, impossible.

Stewartiopteris sp. 1 and sp. 2 (Fig. 7C, D)

The large rachis (Fig. 7C), shows a broad C-shaped xylem strand (arrows, Fig. 7C) and outer sclerenchymatous cortex; it represents the proximal region of 
a frond. The smaller rachis shown on Figure 7D is quite distinct in cortical organization. It certainly corresponds to a second order rachis alongside the corresponding third order rachis (R3, Fig. 7D) which is in connection with a fertile pinnule (P, Fig. 7D). These two Stewartiopteris rachises certainly belonged to different fronds.

Foliage of these tree ferns occasionally occurs as dense accumulations of vegetative and/or fertile pinnules as shown on Figure 7E. One section of an ultimate pinna, paradermal to the pinnule surfaces (Fig. 7F), reveals their pecopteroid morphology. At least three different taxa occur in the assemblage as is suggested by differences in the fertile pinnae.

\section{Pecopteris sp.}

(Fig. 8A)

A transverse section of a vegetative pinnule, similar to those shown on Figure 7E, shows the fleshy texture of the lamina (300-400 $\mu \mathrm{m}$ thick) with palisade and spongy parenchyma; the pinnule margins are flexed downwards and prominent hairs are borne on the lower epidermis. Such pinnules are smaller but very similar in organization to the vegetative pinnules attributed to Scolecopteris oliveri from Autun by Scott \& Holden (1933); they may belong to the same plant as the associated fertile pinnules described hereafter.

\section{Scolecopteris cf. elegans Zenker, 1837}

(Fig. 8B)

This oblique transverse section of one pinnule also shows a lamina with palisade and spongy parenchyma but thin, more than $2 \mathrm{~mm}$ long, lateral extensions

FIG. 8. - Silicified plants from the Permian of Sardinia: A, Pecopteris sp., transverse section of one vegetative pinnule showing thick lamina with palisade and aerenchyma mesophyll. Note the hair (arrow) attached near the lower extremity (SAR15B1T02); B, Scolecopteris cf. elegans Zenker, oblique transverse section

of one pinnule showing two synangia attached on the left side. Note the thick lamina similar to that of Pecopteris sp. (A) but long thin pinnule extension on the right (SAR40C01); C, Scolecopteris cf. parvifolia Millay, part of a longitudinal section of one pinnule passing through several synangia. Note the relatively thin lamina, synangia borne on a short vascularised pedicel and solid tips of sporangia (SAR56AT02); D, E, Scolecopteris cf. alta Millay; D, longitudinal section of a synangium showing the characteristic central column; $\mathbf{E}$, transverse sections of synangia, the one above is through the basal part of the synangium, the other is through the distal region showing only four dehiscent sporangia (SAR01C2B02). Scale bars: $0.5 \mathrm{~mm}$.

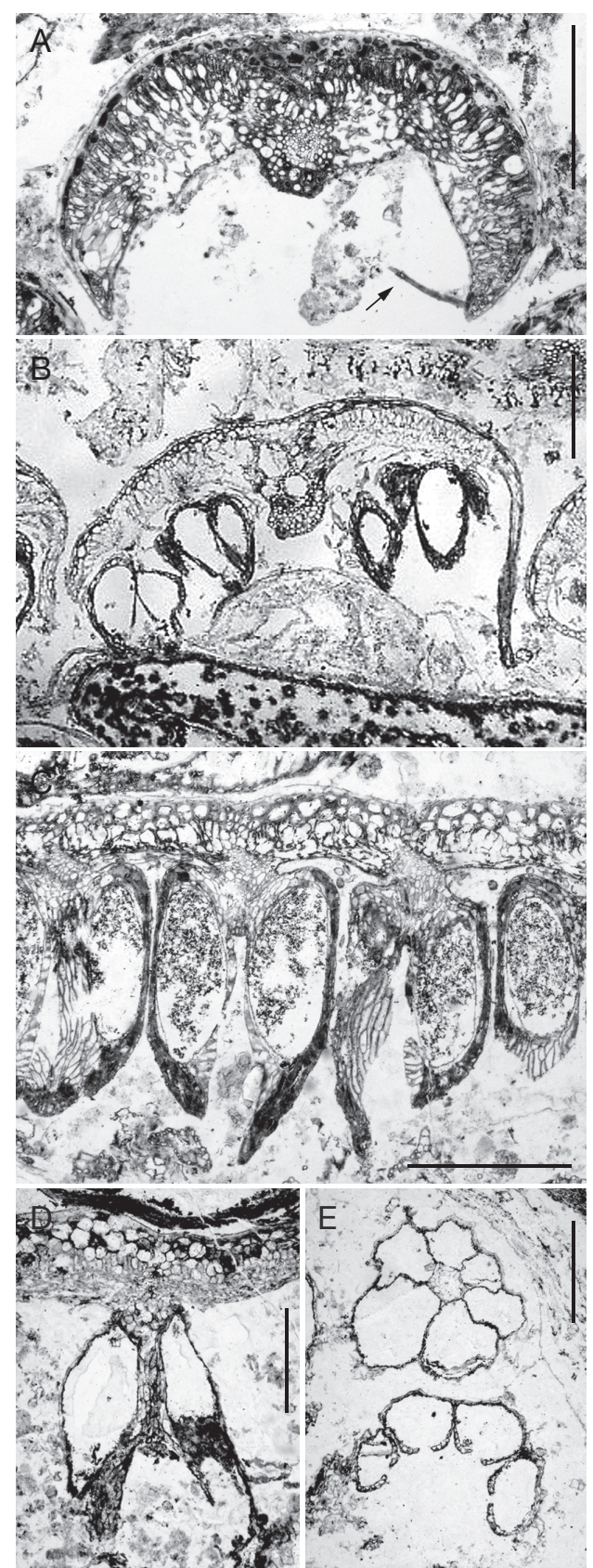


of the lamina enclosing the synangia. These fertile pinnules correspond to those shown in paradermal section on Figure 7F and there is good evidence that they were borne by a rachis of the Stewartiopteris sp. 2 type (Fig. 7D). Despite strong similarities in sporangia and synangiate organization with Scolecopteris oliveri, the sizes of the pinnules (about $2 \mathrm{~mm}$ broad and 4-6 $\mathrm{mm}$ long), synangia and sporangia (less than $1 \mathrm{~mm}$ long) are smaller than those of S. oliveri, according to measurements given by Scott (1932). Moreover, the lateral pinnule extensions are much more pronounced than in S. oliveri; in fact, this Sardinian Scolecopteris rather resembles the organization and size of fertile pinnules of $S$. elegans Zenker, 1837 from the Lower Permian of Saxony (Barthel \& Weiss 1997) or of S. minor Hoskins, 1926 from the Upper Pennsylvanian of Illinois which belong to the Scolecopteris minor group defined by Millay (1979; 1997).

\section{Scolecopteris cf. parvifolia Millay, 1979} (Fig. 8C)

This may represent a second type of fertile parts with large pinnules ( 6 to $8 \mathrm{~mm}$ long and $2-2.5 \mathrm{~mm}$ wide), bearing two rows of up to 14 synangia, each consisting of 4 to 5 sporangia. The lamina is thin $(200 \mu \mathrm{m})$ without a well-marked palisade or spongy tissue; sporangia (up to $0.9 \mathrm{~mm}$ long) are borne on a short vascularised pedicel $(250 \mu \mathrm{m}$ broad $)$ and they are united around this pedicel in their proximal region. The sporangia tips are solid and bluntly pointed. This fertile structure is similar to that of $S$. parvifolia as defined by Millay (1979: pl. 10, fig. 66) from the Pennsylvanian American coal balls.

\section{Scolecopteris cf. alta Millay, 1982} (Fig. 8D, E)

This third type of Scolecopteris is the less common but the most distinctive, with synangia circular in cross section, $0.8 \mathrm{~mm}$ in diameter and more than
$1 \mathrm{~mm}$ long, generally consisting of 6 sporangia fused in their basal half (along about $600 \mu \mathrm{m}$ ) around a central column of parenchyma and fibers. Sporangia are less than $1 \mathrm{~mm}$ long and 200-400 $\mu \mathrm{m}$ in diameter with thin outer walls, even in their free distal region (Fig. 8E). The synangium pedicels are very short, broad $(600 \mu \mathrm{m})$, parenchymatous and attached to relatively thick $(400 \mu \mathrm{m})$ pinnules showing large mesophyll cells (Fig. 8D) but there is no well-differentiated palisade tissue. These fertile pinnules clearly belong to the "Altus group" of Millay (1979) and they appear more similar to the Pennsylvanian Scolecopteris alta (Watson) Millay, 1982. The present material may also be compared to Scolecopteris globiforma from Grand-Croix and $S$. unita from the Lower Permian of Autun (Millay \& Galtier 1990), however, these two species differ from the Sardinian pinnules by their thick outer sporangial walls bearing hairs.

These fertile fronds of marattialeans represent one of the most important elements of the flora but the taxonomic elucidation needs additional investigation, which is out of the scope of this paper - it will be the object of a separate, detailed study.

However, we wish to emphasize that the three distinct types of Scolecopteris show differences in pinnule morphology and sporangial organization suggesting an important diversity of marattialeans at Perdasdefogu. In a palaeoecological perspective it is significant that most show rather thick pinnules (? xeromorph) which may have been efficient for water conservation in drier environments (see Barthel \& Weiss 1997).

\section{SEED PLANTS}

Fragments of seed plants occur in less than 1 of 4 specimens; they correspond to stems, leaves, rachises, seeds and pieces of cortex and wood of pteridosperms or cordaiteans.

Petiole or rachis of Heterangium type (Fig. 9J) Such isolated rachises with up to 6 mesarch bundles (arrows, Fig. 9J) resemble petioles of some

FIG. 9. - Silicified plants from the Permian of Sardinia: A, Cordaixylon sp., transverse section of a partly decorticated small stem with a solid parenchymatous pith; on the left the closely associated rachis $(\mathbf{P})$ with several xylem bundles may represent a petiole of the same plant (SAR24B4L13); B, Cordaites leaves associated with Pecopteris pinnules; the broadest leaf (CC) with interfascicular scleren- 


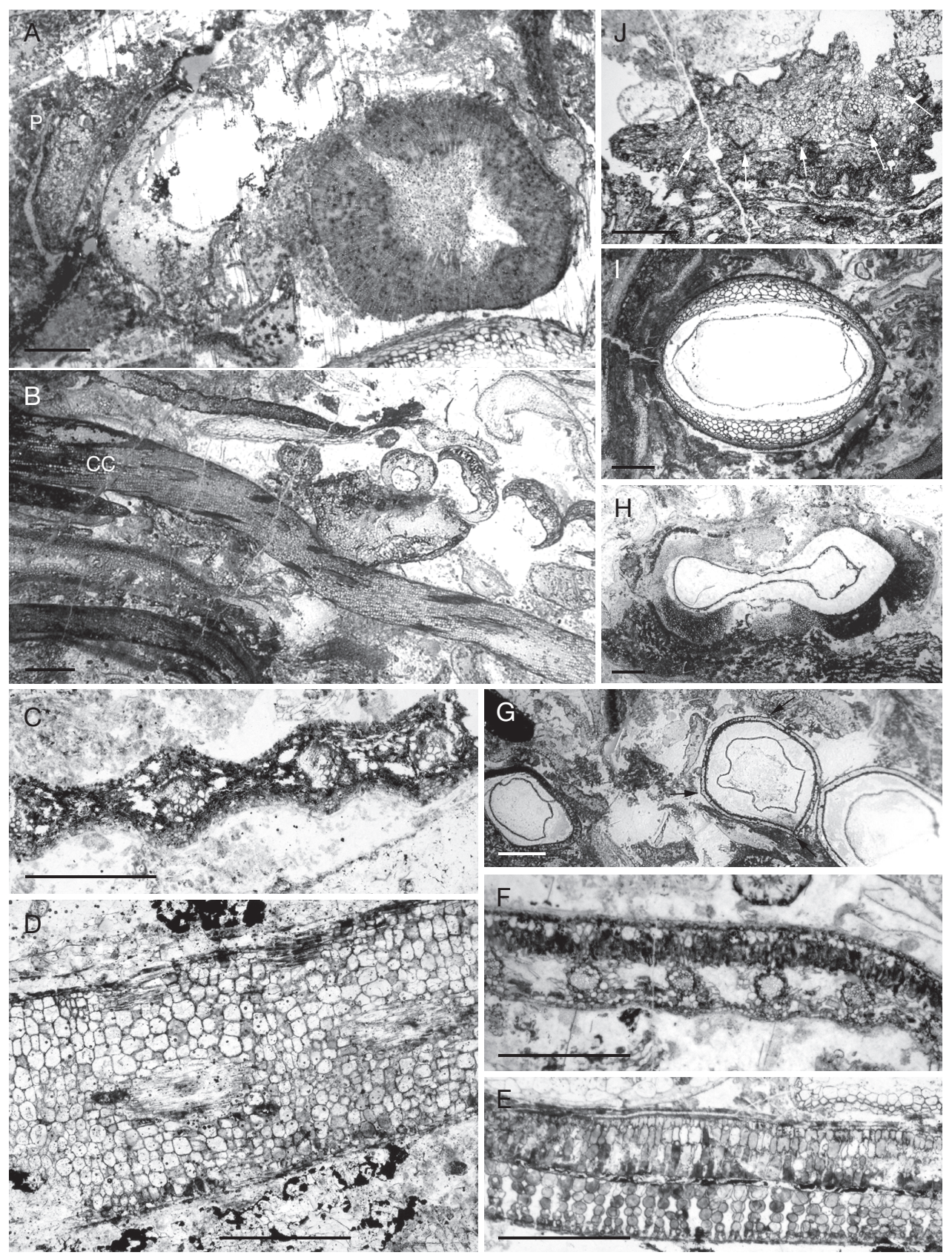

chyma strands conforms to the species C. crassus Renault (SAR01AS03); C-E, SAR01B1aB01; C, Cordaites tenuistriatus Grand'Eury, detail of transverse section of the lamina; D, Cordaites cf. crassus, detail of transverse section of the thick lamina; E, Cordaites sp., detail of a longitudinal section of the lamina showing excellent preservation of the mesophyll; F, Cordaites cf. lingulatus Grand'Eury, transverse section of lamina (SAR24B4L07); G, transverse section of three small radially symmetrical ovules showing three sutures (arrows) of the sclerotesta (SAR47A1B01); H, Cycadinocarpus augustodunensis (Brongniart) Renault, transverse section of the ovule (SAR15BT01); I, cf. Parataxospermum, transverse section of the ovule (SAR40C2T09); J, rachis of possible lyginopterid affinities showing five mesarch xylem bundles (arrows). Scale bars: A, B, G-J, $1 \mathrm{~mm}$; C-F, $0.5 \mathrm{~mm}$. 


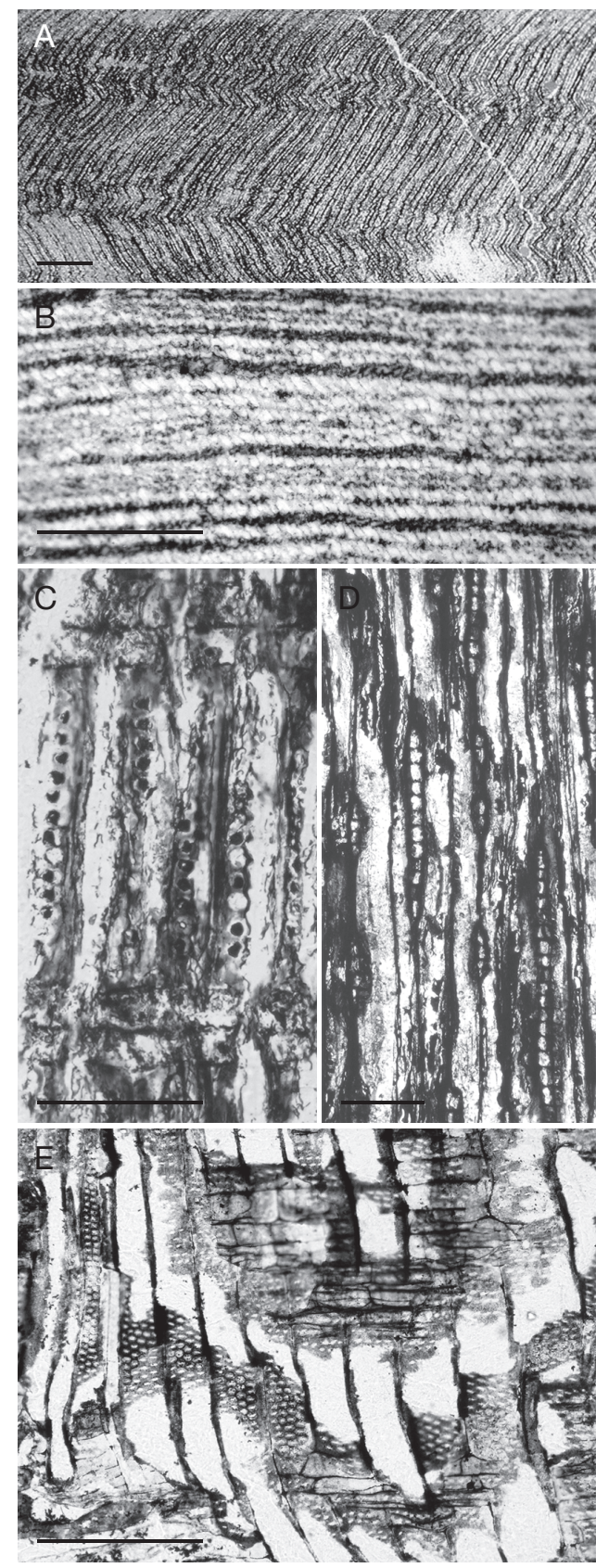

FIG. 10. - Silicified plants from the Permian of Sardinia: A-D, Dadoxylon cf. rollei Unger, isolated wood fragment; A, transverse section showing the distorted files of tracheids (SAR07BB03);

B, detail of the same showing rows of tracheids separated by narrow rays; C, radial longitudinal section showing poorly preserved uni-to biseriate circular pits of tracheids between two rays (SAR07BLR01); $\mathbf{D}$, tangential longitudinal section showing the narrow (uniseriate) rays of variable height (SAR07AL07); E, isolated wood of pteridosperm affinities, radial longitudinal section showing the broad tracheids with multi (4 to 5)-seriate pitting (SARBB02). Scale bars: A, $1 \mathrm{~mm} ; \mathrm{B}, 0.5 \mathrm{~mm}$; C-E, $100 \mu \mathrm{m}$.
Pennsylvanian Heterangium illustrated by Pigg et al. (1987). Heterangium stems are known from the Lower Permian of Autun but they have not yet been found at Perdasdefogu.

\section{Radially symmetrical ovules (Fig. 9G)}

These rare, very small ovules $(2.5$ to $3 \mathrm{~mm}$ in diameter) show a well-marked radial symmetry with evidence of three sutures of the sclerotesta (arrows, Fig. 9J). Despite their small size, this is suggestive of affinities with medullosan pteridosperms.

\section{Probable medullosan wood (Fig. 10E)}

A few fragments of wood, sometimes fusinized, show very broad tracheids (60-100 $\mu \mathrm{m}$ in diameter) with multiseriate ( 3 to 5 -seriate) pitting on their radial walls and high multiseriate rays; they have characteristics of pteridosperm secondary xylem and may be attributed with some reservation to medullosans. This is supported by the occurrence of fragments of outer cortex, with parenchyma and sclerenchyma strands, of the sparganum-type which are characteristic of the stem and rachises of this group of seed ferns.

\section{Cordaixylon sp. (Fig. 9A)}

We illustrate a small, partly decorticated stem, about $6 \mathrm{~mm}$ in diameter. The cylinder of secondary xylem averages $4 \mathrm{~mm}$ and the pith $1.5 \mathrm{~mm}$ in diameter. The wood tracheids are small, ranging from 12-15 $\mu \mathrm{m}$ in diameter for the innermost ones to $20-30 \mu \mathrm{m}$ in diameter at the periphery. The endarch maturation of the primary xylem conforms to the genus Cordaixylon Grand'Eury. On the surfaces studied the pith is solid and consists of a parenchyma of small cells (around $30 \mu \mathrm{m}$ in diameter). One incomplete rachis, crescentshaped in cross section (P, Fig. 9A), is closely associated with the stem; it certainly represents one petiole of this plant, as suggested by its vascular anatomy consisting of more than six bundles as it should be expected in the petiole of such a young cordaitean stem. Associ- 

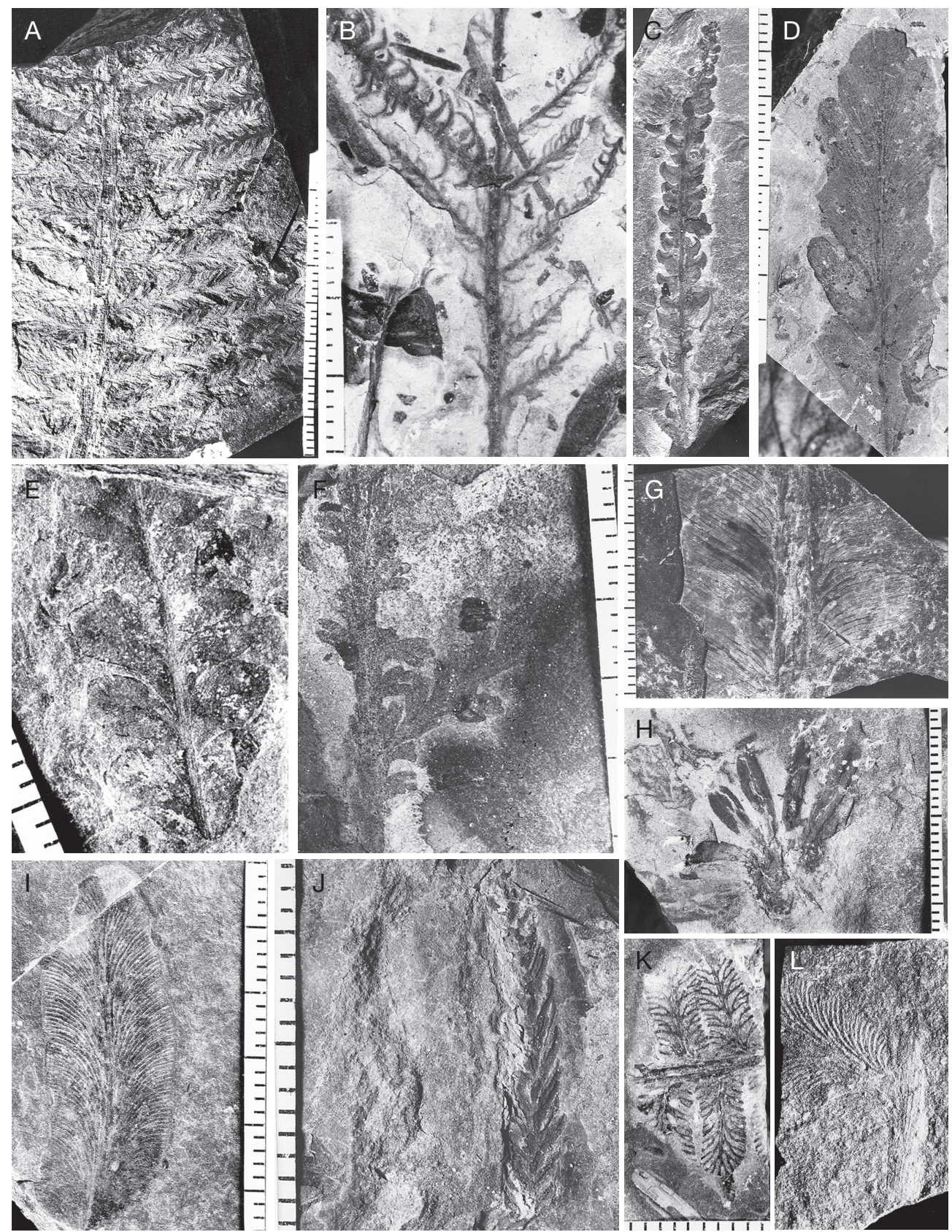

FIG. 11. - Representative elements of the compression macroflora from Sardinia; A, Walchia piniformis Sternberg; B, C, Ernestiodendron filiciforme (Sternberg) Florin; D, Rhachiphyllum schenkii (Heyer) Kerp; E, Autunia conferta (Brongniart) Haubold \& Kerp; F, Rhachiphyllum lyratifolia (Goeppert) Kerp; G, Taeniopteris abnormis Gutbier; H, Annularia mucronata Schenk; I, Odontopteris lingulata; J, Otovicia hypnoides (Brongniart) Kerp et al.; K, Pecopteris cf. densifolia (Goeppert) Weiss; L, Neuropteris osmundae (Artis) Kidston. Scale bar graduations: $1 \mathrm{~mm}$; B and $\mathrm{C}$ are at the same scale; $\mathrm{L}$ and $\mathrm{K}$ are at the same scale. 
ated in the same chert block we found fragments of leaves with a thin lamina (Fig. 9F, see below).

\section{Cordaites leaves}

Some rock specimens contain diverse cordaitean leaves interspersed among leaves of other plants (Fig. 9B). These leaves, of different thickness and anatomy, are illustrated at the same magnification on Figure 9C-F.

\section{Cordaites tenuistriatus Grand'Eury, 1877} (Fig. 9C)

In this leaf the lamina is thin and of variable thickness: $0.2 \mathrm{~mm}$ between veins to $0.4 \mathrm{~mm}$ at the level of veins due to the presence of triangular hypodermal sclerotic strands above and below the bundle sheath. This results in a typical superficial ribbing characteristic of the species $C$. tenuistriatus as illustrated by Renault (1879) from the Pennsylvanian of Grand-Croix. The interval between veins is less than $0.6 \mathrm{~mm}$, i.e. about 17 veins per $\mathrm{cm}$.

Cordaites cf. crassus Renault, 1879

(Fig. 9B [CC]; 9D)

In contrast, this leaf found associated with the previous one, shows a very thick (up to $1 \mathrm{~mm}$ ) lamina and a superficial surface smooth. Sclerotic strands do not extend to the bundle sheath and intermediate strands occur between veins as illustrated by Renault (1879) for specimens from Grand-Croix and by Harms \& Leisman (1961) from American Pennsylvanian coal balls. The interval between veins is about $0.7 \mathrm{~mm}$, i.e. about 14 veins per $\mathrm{cm}$.

Cordaites cf. lingulatus Grand'Eury, 1877 (Fig. 9F)

This leaf, found associated with the stem of Figure $9 \mathrm{~A}$, has a thin lamina $(0.4 \mathrm{~mm})$, a smooth surface and very closely spaced veins (less than $0.4 \mathrm{~mm}$ interval, i.e. about 25 per $\mathrm{cm}$ ). Rectangular sclerotic strands extend above and below veins; the mesophyll is differentiated into palisade and more or less spongy tissues. Despite similarities with the species $C$. lingulatus Grand'Eury as illustrated by Renault (1879) this leaf may represent variability of other species like Cordaites principalis Germar, as illustrated by Harms \& Leisman (1961).

\section{Cordaites sp.}

(Fig. 9E)

This radial section shows the excellent preservation of the lamina with vertical mesophyll plates separated by lacunae and palisade-like tissue in a leaf similar to the previous one.

\section{Cycadinocarpus augustodunensis}

(Brongniart) Renault, 1896

(Fig. 9H)

Groups of dispersed ovules of this type are found in a few specimens. They are up to $9 \mathrm{~mm}$ long , 6-8 $\mathrm{mm}$ wide in the major plane and 3-5 mm wide in the minor plane of symmetry. They conform to the description of the species Cycadinocarpus augustodunensis (Brongniart) Renault (1896) from Autun. This ovule was previously described as Cordaicarpus augustodunensis by Brongniart (1881). The generic change, from Cordaicarpus to Cycadinocarpus, proposed by Renault (1896) was supported by Bertrand (1908). This ovule is mostly characterized by the irregular sclerotesta varying greatly in thickness and appearing trabeculate in tangential sections (Brongniart 1881: pl. III, fig. 14). Original type material of this species, kept in the Muséum national d'Histoire naturelle, Paris (MNHN), has been re-investigated by one of the authors (JG) and the non-artefactual nature of this irregular slerotesta was confirmed as well as the specific identification of the Sardinian ovules to the species of Autun.

\section{cf. Parataxospermum}

(Fig. 9I)

Dispersed cardiocarpalean ovules of this type are the most common, occurring in about $1 / 10$ of specimens. 
They are up to $1 \mathrm{~mm}$ long and $6 \times 5 \mathrm{~mm}$ wide. They are characterized by a prominent sclerotesta up to $1 \mathrm{~mm}$ thick composed of large thick-walled cells 50 to $200 \mu \mathrm{m}$ in diameter gradually decreasing in size in the outermost sclerotesta and near the base of the ovule. Detailed description of these ovules will be presented in another paper but it is worth mentioning that they are most similar with ovules from Carboniferous-Permian coal balls from Shanxi Province in China described by Li (1993).

Dadoxylon cf. rollei Unger, 1859

(Fig. 10A-D)

A rather large specimen consists of a single fragment of distorted wood (Fig. 9A); however characteristic features are preserved: the files of secondary xylem tracheids (30-50 $\mu \mathrm{m}$ in diameter) are separated by narrow (uniseriate) rays of variable height (2 to 20 cells) (Fig. 9B, D); pitting, restricted to radial walls, shows uni- to biseriate rows of crowded circular bordered pits (Fig. 9C). This anatomy is similar to that of woody trunks of Dadoxylon rollei Unger from the Lower Permian of Germany and from Autun. Marguerier (1971), who investigated trunks from Autun, consider that characteristics of tracheid pittings of such woods suggest affinities with walchian conifers rather than with cordaites.

\section{DISCUSSION}

\section{COMPOSITION OF THE PLANT ASSEMBLAGE AND COMPARISON WITH THE AUTUN AND OTHER PERMINERALIZED FLORAS}

Even if some sectioned chert blocks contained several tens of identifiable plant remains, our analysis of the occurrence of organs and taxa concerns less than one hundred chert specimens and may not be considered as a significant quantitative analysis. However, this preliminary inventory of the permineralized flora provides some indication on the relative occurrence of plants and organs. As shown on Figure 12A, the most common plants are calamiteans and tree ferns before cordaiteans, small filicalean ferns, seed ferns and Sphenophyllum. Roots - of calamiteans
A

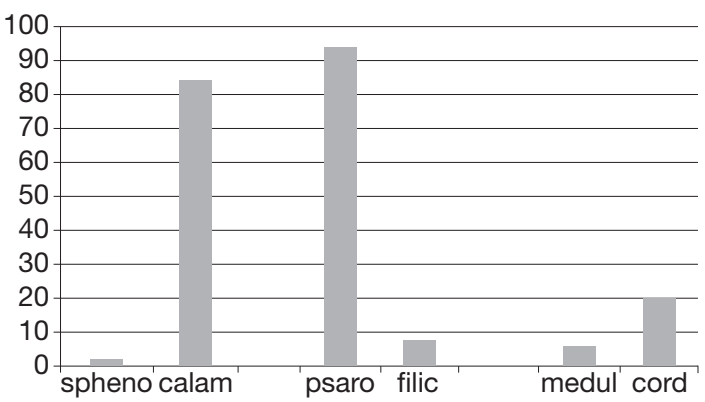

B

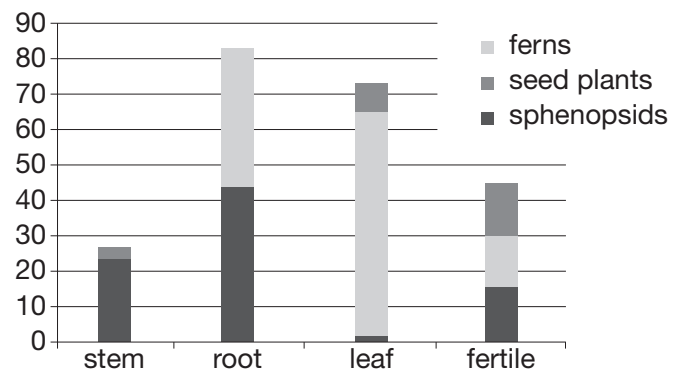

FIG. 12. - Composition of the permineralized plant assemblage: A, abundance of taxa expressed by the number of chert specimens containing sphenophyllean (spheno) and calamitean (calam) sphenopsids, marratialean/psaroniacean (psaro) and filicalean ferns (filic), medullosan (medul) and cordaitean (cord) seed plants; B, abundance of organs by taxa expressed by the number of chert specimens containing stem, root, leaf and fertile parts, respectively of sphenopsids, ferns and seed plants.

often co-occuring with detached Psaronius aerial roots - are the most common organs before leaves mainly belonging to ferns (Fig. 12B). In contrast, the stems, mainly represented by calamiteans, are less common whilst fertile parts belonging to ferns, calamitean cones and cordaitean ovules are about equally represented.

With regard to taxa, the most common elements are Pecopteris-Scolecopteris which correspond to vegetative and fertile leaves of at least three different species of marattialean ferns also represented by Stewartiopteris rachises and Psaronius fragments of stems and root mantle. Astromyelon-Myriophylloides roots are also common whilst Arthropitys occurs as fragments ranging from young twigs to large woody stems. Together with Palaeostachya cones, these ca- 
lamitean remains may correspond to different parts of the same whole plant. Cordaites leaves, ovules and stems are rare while representatives of other groups (sphenophylls, tedelean and anachoropterid ferns, and seed ferns) are still less frequent. One must note the occurrence of rootlets as the only indication of the presence of (?sigillarian) lycopsids and of a $D a$ doxylon wood of possible conifer affinity.

Like in coal balls, the present plant assemblage consists of an accumulation of roots and aerial organs (mainly of tree ferns and calamitean) which is suggestive of little or no transport and may be interpreted as a litter with autochtonous to parautochtonous elements.

It is interesting to compare these results to quantitative analysis carried out previously on silicified material from the Late Pennsylvanian of GrandCroix and the Lower Permian of Autun (France) following procedures of Phillips et al. (1977) using a transparent overlay grid system $\left(1 \mathrm{~cm}^{2}\right)$. This study (Galtier \& Phillips 1985) revealed a difference between the two French assemblages with cordaiteans dominating the Grand-Croix vegetation, as confirmed by a recent study of Galtier (2008), whilst tree ferns and calamiteans dominated in Autun. This difference was interpreted in terms of environment and ecology. It is certainly very significant that the new assemblage from Sardinia is dominated by tree ferns and calamiteans like the contemporaneous silicified vegetation of Autun. However, the long studied flora from Autun is very rich ( 35 genera and 73 species) and can hardly be compared to the Perdasdefogu flora that is limited to about 16 genera and a little more than twenty taxa according to this preliminary study. However, it is significant that all the genera found at Perdasdefogu, except Parataxospermum, are present in Autun as well as several species including the ovule Cycadinocarpus augustodunensis which is, up to now, only known from these two assemblages. It must be noted also that a number of taxa (e.g., Arthropitys bistriata, Ankyropteris brongniartii, Scolecopteris elegans) are in common with the Early Permian floras from the Döhlen Basin of Germany (Barthel et al. 1995; Rössler 2006). The similarity between permineralized floras of Perdasdefogu and Autun is further supported by the comparison of the associated compression floras of the two basins.
COMPRESSION MACROFLORAS OF THE

PERDASDEFOGU BASIN AND SPOROMORPH ASSEMBLAGES

Among a large number of macroflora specimens collected from the underlying lithofacies $c$ (black siltstones) (Broutin et al. 1996; Ronchi et al. 1998; Broutin et al. 2000a; Cassinis \& Ronchi 2002) one must point out the presence of the following plants: Asterophyllites longifolius (Sternberg) Brongniart, Annularia mucronata Schenk (Fig. 11H), Pecopteris elaverica Zeiller, Odontopteris lingulata (Goeppert) Schimper (Fig. 11I), Neuropteris osmundae (Artis) Kidston (= Odontopteris dufresnoyi) (Fig. 11L), Taeniopteris abnormis Gutbier (Fig. 11G), Autunia (al. Callipteris) conferta (Brongniart) Haubold \& Kerp (Fig. 11E), Rhachiphyllum (al. Callipteris) schenkii (Heyer) Kerp (Fig. 11D), Rhachiphyllum (al. Callipteris) lyratifolia (Goeppert) Kerp (Fig. 11F), Dichophyllum (al. Callipteris) flabellifera (Weiss) Kerp \& Haubold, Lodevia (al. Callipteris) nicklesii (Zeiller) Haubold \& Kerp, Ernestiodendron filiciforme (Sternberg) Florin (Fig. 11B, C), Otovicia (al. Walchia) hypnoides (Brongniart) Kerp et al.(Fig. 11J), Walchia piniformis Sternberg (sensu Visscher et al. 1986) (Fig. 11A), Culmitzchia (al. Lebachia) laxifolia (Florin) Clement-Westerhof.

According to Broutin (in Ronchi et al. 1998; Broutin et al. 1999, 2000a) the Perdasdefogu macrofloras permit to relate these strata to the middle-upper Autunian of the French Massif central and more precisely to the Surmoulin and Millery formations ("Upper Autunian” A3 association; Doubinger 1974) of the Autun Basin (Chateauneuf et al. 1992) and to the Catalan Pyrénées basins (Gerri de la Sal succession, Sierra del Cadì; Dalloni 1930; Gisbert 1983, 1984; Broutin unpublished revision). This is in agreement with the upper Asselian to Asselian-Sakmarian transition time-interval pointed out by the amphibian species found in strata immediately below, and perfectly correlatable with the same association found in Gottlob-lake (Thuringian Forest Basin: Werneburg et al. 2007).

Within the same deposits yielding macrofloras a rich sporomorph association has been found. The palynological assemblage of the Perdasdefogu Basin, except for the local characteristics, displays 
the same qualitative and quantitative composition, both at generic and specific levels, as that recorded from the Punta Lu Caparoni Formation (Broutin et al. 2000b) in Nurra (NW Sardinia). These two very similar associations can be compared with that defined by J. Doubinger (1974), for the biozone "A3", in her revision of the Autunian of Europe.

Both are dominated by monosaccate pollen grains, the Potonieisporites "novicus-bhardwajii" complex being especially diversified and constituting some $50 \%$ of the total assemblage. Bisaccate grains (20\%) are associated with typical "Autunian" genera such as Vittatina or Costapollenites. The following groups and species have been identified:

- spores: Convolutispora sp. 2 (Peppers 1964), Verrucosisporites spp., Laevigatosporites spp., Lundbladispora sp.;

- pollen: monosaccates: Potonieisporites novicusbharadwajii, Florinites diversiformis, F. mediapudens, Florinites spp., Nuskoisporites cf. klausii; non-striate bisaccates: Vesicaspora ovata, Gardenasporites leonardii, Illinites tectus, Illinites spp., Limitisporites spp.; striate bisaccates: Protohaploxypinus samoilovichii, Protohaploxypinus sp., Hamiapollenites sp., Straitoabieites sp.; plicates: Vittatina ovalis, Vittatina sp., Costapollenites sp.

The Perdasdefogu sporomorph association was also discussed in a review on the Permo-Carboniferous to Triassic palynofloral association by Pittau \& Del Rio (2002). For these authors, the proposed correlation of the Perdasdefogu palynoflora to biozone "A3" of the Autunian of Europe leaves some doubts with regard to the age of these assemblages, in the light of the controversy that still surrounds the status of the Autunian stage and its correlations with the standard scale that have still to be ascertained. According to a more recent paper by Pittau et al. (2008) the preservation of Perdasdefogu sporomorphs is poor and therefore a qualitative and quantitative assessment of the palynoflora is difficult; it would even be difficult to determine whether Florinites or Potonieisporites is the dominant pollen genus. Therefore, for these authors, the sporomorph assemblages of this basin might be compared with the younger Lu Capparoni assemblages, or even with the older Seui-Seulo assemblage.

\section{Palaeogeographic and palaeoclimatic interpretation} From a palaeogeographical point of view, it is significant that a very similar compression flora has been recorded from Lodève (southern France) and from the Catalan Spanish Pyrenees: this is in agreement with the palaeoposition proposed by Broutin et al. (1994), based on structural and magmatic data, and later confirmed by Cassinis \& Ronchi (2002) and Cassinis et al. (2003): the Sardinian block is aligned in an East-West direction linking northwestern Sardinia with the Provencal area and, at least the central part of the island, with the southern Pyrenean domain.

The dominance of black shaley siliciclastics (lithofacies $c$ ) and the repeated occurrence of millimetreto-pluricentimetre thick anthracite horizons in lithofacies $d$ (boghead coal?) could suggest a frequent cyclic alternation of marsh and lacustrine environments. The Rio su Luda Formation environments thus indicate a humid to semi-humid climate. Very few indicators for dry conditions, such as mud-cracks or clay chips, occur in the siliciclastic part of the sequence (lithozone c), whereas tepeelike structures appear in the uppermost part of the freshwater limestones of lithofacies $d$, indicating a major lake emersion event.

On the basis of facies analysis of the Autunian Sardinian sequences, Ronchi et al. (2008) infer climatic conditions of high precipitation dominated by monsoonal and seasonal to subseasonal cycles of prolonged rainfall and shorter dry periods. Lithofacies and palaeontological records confirm such wet climatic phases, which interrupted the overall Permo-Carboniferous aridisation trend as indicated by Schneider et al. (2006) and Roscher \& Schneider (2006). According to Ronchi et al. (2008), the Perdasdefogu Basin sequence seems to fall into the "topmost Lower Rotliegend wetness phase" of Schneider et al. (2006) (Asselian/Sakmarian transition). This humid to semihumid phase, recognized by Ronchi et al. (2008) also in other basins of Sardinia (Escalaplano, Lu Caparoni), is characterized by a complex intercalation of alluvial fan and fluvial conglomerates, wet alluvial plain and perennial lacustrine fine clastics, lacustrine black-shales and limestones, sometimes decimetre-thick coal seams and frequent pyroclastic horizons. A slight 
change towards warmer climatic conditions was envisaged in the microfloristic associations of the Lu Caparoni and Perdasdefogu basins by Pittau et al. (2002). The sporomorph assemblages of such basins lack numerous taxa with respect to Guardia Pisano (Sulcis) and, according to these authors, this could reflect even dryer conditions during the late Asselian. The similarity between the Lu Caparoni and Perdasdefogu megafloras, indicated by Broutin et al. (1999), suggests that the two basins developed under similar climatic conditions and were likely coeval. In contrast, according to Pittau et al. (2008), the Lu Caparoni palynological assemblage differs sufficiently (relative abundance of taeniate pollen is considerably higher than in those of southwestern and central-eastern basins) to allow the recognition of a different ecostratigraphic unit, which they called the Vittatina-Striatiti pollen Phase. This phase corresponds to a notable increase of the genera Vittatina, Hamiapollenites, Protohaploxypinus with a consistent reduction of Potonieisporites and Florinites prepollen. The high percentage of pteridosperms producing striate pre-pollen and pollen grains is indicative of an increase of arid or less humid habitats. These new palynological data lead to postulate that the Lu Caparoni basin was not "coeval" with the Perdasdefogu one, as suggested on the base of their megafloras, but slightly younger. Therefore, the intercalibration between the micro- and megafloral zonations for the Asselian-Sakmarian time span in this area remains to be established using the other data sets available.

\section{Acknowledgements}

We are indebted to G. Gand and an anonymous reviewer for their helpful remarks and constructive criticism. This research was partially funded by PRIN 2008 grants (G. Oggiano resp.).

\section{REFERENCES}

ARCANGeli G. 1901. - Contribuzione allo studio dei vegetali permo-carboniferi della Sardegna. Paleontografica Italica: 91-120.

ARTHAUd A. \& MatTe P. 1977. — Late Paleozoic strikeslip faulting in southern Europe and northern Africa: result of a right-lateral shear zone between the Appalachians and the Urals. Geological Society of America Bulletin 88: 1305-1320.

Barthel M., Reichel W. \& Weiss H.-J. 1995. "Madensteine" in Sachsen. Neue Funde von Scolecopteris elegans zenker in der Typus-Lokalitat. Abhandlungen des Statlichen Museum Mineralogie und Geologie, Dresden 41: 117-135.

BARTHEL M. \& WeisS H.-J. 1997. — Xeromorphe Baumfarne im Rotliegend Sachsens. Veröffentlichungen des Museum für Naturkunde Chemnitz 20: 45-56.

BAXTER R.W. 1954. - Palaeostachya andrewsii, a new species of calamitean cone from the American Carboniferous. American Journal of Botany 42: 342-351.

Boureau E. 1964. - Traité de Paléobotanique. III. Sphenophyta, Noeggerathiophyta. Masson, Paris, 544 p.

BERTRAND C. E. 1908. - Les caractéristiques du Cycadinocarpus augustodunensis de B. Renault. Comptes rendus de l'Académie des Sciences, Paris 146: 326-333.

BRONGNIART A. 1881. - Recherches sur les graines fossiles silicifiées. Masson, Paris, 94 p.

Broutin J., Cabanis B., Chateauneuf J.-J. \& Deroin J.P. 1994. - Évolution biostratigraphique, magmatique et tectonique du domaine paléotéthysien occidental (SW de l'Europe) : implications paléogéographiques au Permien inférieur. Bulletin de la Société géologique de France 165 (2): 163-179.

Broutin J., Cassinis G., Cortesogno L., Gaggero L., RONCHI A. \& SARria E. 1996. - Research in progress on the Permian deposits of Sardinia (Italy), Permophiles 28: 45.

Broutin J., ChÂteauneuf J.-J., Galtier J. \& Ronchi A. 1999. - L'Autunien d'Autun reste-t-il une référence pour les dépots continentaux du Permien inférieur d'Europe? Géologie de la France 2: 17-31.

Broutin J., Diez J.-B., Freytet P., Galtier J., Lethiers F., Ronchi A. \& Tintori A. 2000a .- The Early permian Perdasdefogu Basin: stratigraphy and volcanism. Paleontological data. Excursion 2: Early Permian basins in southeastern Sardinia (Gerrei and Ogliastra), in Cassinis G., Cortesogno L., GaGgero L., Pittau P., Ronchi A. \& Sarria E. (eds), Late Palaeozoic Continental Basins of Sardinia. Field Trip Guidebook, Inter. Field Conference on "The Continental Permian of the Southern Alps and Sardinia (Italy). Regional Reports and General Correlations". 15-25 Sept. 1999, Brescia: 75-83.

Broutin J., Diez J.-B. \& Ronchi A. 2000b - The Lower Permian Deposits of Punta Lu Caparoni. Palaeontological data, in CASSINIS G., CORTESOGNO L., Gaggero L., Pittau P., Ronchi A. \& Sarria E. (coordinators), Late Palaeozoic Continental Basins of Sardinia. Field Trip Guidebook, Inter. Field Conference on "The Continental Permian of the Southern Alps and Sardinia (Italy). Regional Reports and General Correlations". 15-25 Sept. 1999, Brescia: 98-101. 
CASSINIS G. 1996. - Upper Carboniferous to Permian stratigraphic framework of Southwestern Europe and its implications. An overview, in MOULLADE N. \& NAIRN A. E. M. (eds), The Phanerozoic Geology of the World. I, The Palaeozoic. Elsevier, Amsterdam: 109-180.

CAssinis G. \& Ronchi A. 2002. - The (late-) postVariscan continental succession of Sardinia. Rendiconti della Societa di Paleontologia Italiana 1: 77-92.

Cassinis G., Cortesogno L., GagGero L. \& RONCHI A. 1998. - Osservazioni preliminari sulle successioni continentali permiane della Sardegna. Rendiconti Istituto Lombardo Accademia di Scienze e Lettere, B 130: 177-205.

Cassinis G., Cortesogno L., Gaggero L., Pittau P., Ronchi A. \& Sarria E. (eds) 2000. — Late Palaeozoic Continental Basins of Sardinia. Field Trip Guidebook, Inter. Field Conference on "The Continental Permian of the Southern Alps and Sardinia (Italy). Regional Reports and General Correlations". 15-25 Sept. 1999, Brescia, $116 \mathrm{p}$.

CAssinis G., Durand M. \& RonChi A. 2003. — PermianTriassic continental sequences of northwest Sardinia and south Provence: stratigraphic correlations and palaeogeographic implications, in DECANDiA F. A., CASSINIS G. \& SpInA A. (eds), Special Proceedings of the Scientific Meeting "Late Palaeozoic to Early Mesozoic events of Mediterranean Europe, and additional regional reports", Siena, 2001. Italian Journal of Geoscience, Vol. Spec. 2: 119-129.

Chateauneuf J. J., Farjanel G., Pacaud G. \& Broutin J. 1992. - The Autun Permian Basin, the Autunian stratotype, in Permian Basins in the French Massif Central. 8th International Palynological Congress, Aix-en-Provence, 13-16th sept. 1992, Excursion E. Cahiers de Micropaléontologie 7 (1-2): 123-139.

COMAschi Caria I. 1959. - Le piante fossili della Sardegna. Memorie della Rivista Italiana di Paleontologia e Stratigrafia 7: 1-176.

Corsin P. 1937. - Contribution à l'étude des Fongères anciennes du groupe des Inversicaténales. Sautai, Lille, $247 \mathrm{p}$.

Cortesogno L. \& Gaggero L. 2000. - The Early Permian Perdasdefogu Basin: stratigraphy and volcanism. Volcanic activity. Excursion 2: Early Permian basins in southeastern Sardinia (Gerrei and Ogliastra), in Cassinis G., Cortesogno L., GagGero L., Pittau P., Ronchi A. \& Sarria E. (eds) (2000), Late Palaeozoic Continental Basins of Sardinia. Field Trip Guidebook, Inter. Field Conference on "The Continental Permian of the Southern Alps and Sardinia (Italy). Regional Reports and General Correlations". 15-25 Sept. 1999, Brescia: 84-85.

Cотта B. 1832. - Die Dendrolithen in Beziehung auf ihren inneren Bau. Arnoldische Buchhandlung, Leipzig and Dresden, $89 \mathrm{p}$.
Dalloni J. 1930. — Étude géologique des Pyrénées catalanes. Annales de la Faculté des Sciences de Marseille 26 (3), $373 \mathrm{p}$.

Doubinger J. 1974. - Études palynologiques dans l'Autunien. Review of Palaeobotany and Palynology 17: 21-38.

FoIs F. 1939. - Note geologico-minerarie sul bacino carbonifero di Perdasdefogu. Resoconti dell'Associazone mineraria Sarda 44: 115-128.

Freytet P., Galtier J., Schneider J., Ronchi A., Tintori A. \& Werneburg R. 2002. - Early Permian biota from Southeastern Sardinia (Ogliastra and Gerrei). Rendiconti della Societa di Paleontologia Italiana 1: 169-176.

Galtier J. 2008. - A new look at the permineralized flora of Grand-Croix (Late Pennsylvanian, SaintÉtienne basin, France). Review of Palaeobotany and Palynology 152: 129-140.

GAltier J. \& Phillips T. L. 1985. — Swamp vegetation from Grand'Croix (Stephanian) and Autun (Autunian), France and comparaison with Coal Ball Peats of Illinois Basin. Comptes Rendus du 9ème Congrès International de Stratigraphie et Géologie du Carbonifere, Urbana, USA 5: 13-24.

Galtier J. \& Phillips T. L. 1999. — The acetate peel technique, in Jones T. P. \& Rowe N. P. (eds), Fossil Plants and Spores: Modern Techniques. The Geological Society, London: 67-70.

Gisbert J. 1983. - El Permico de los Pirineos Españoles, in Diaz C. M. (ed.), Comptes rendus du 10 Congrès international de stratigraphie et géologie du Carbonifere. Ministerio de Industria y Energia, Madrid: 403-420.

GISBERT J. 1984. - Les Molasses post-hercyniennes dans le Haut Urgell et la Cerdagne occidentale (Pyrénées Catalanes, Espagne). Comptes Rendus de l'Académie des Sciences de Paris 298, série II, 20: 883-888.

Harms V. L. \& Leisman G. A. 1961. - The anatomy and morphology of certain Cordaites leaves. Journal of Paleontology 35: 1041-1064.

HoskINS J. H. 1926. - Structure of Pennsylvanian plants from Illinois. Botanical Gazette 82: 427-437.

Li Z. M. 1993. - Studies on Parataxospermum taiyuanensis gen. et sp. nov. from coal balls. Review of Palaeobotany and Palynology 77: 65-74.

Lombardi G., COZZUPOLI D. \& NiCOleTti M. 1974. Notizie geopetrografiche e dati sulla cronologia K-Ar del vulcanismo tardopaleozoico sardo. Periodico di Mineralogia 43: 221-312.

Marguerier J. 1971. - À propos d'un bois fossile de l'Autunien d'Autun: Dadoxylon rollei Unger, bois présumé de coniférophyte. Comptes Rendus du 96e Congrès national des Sociétés Savantes, Toulouse, Sciences 5: 77-97.

MaXIA C. 1938. - Alcune osservazioni sulla flora autuniana di Perdasdefogu e sul Paleozoico recente 
della Sardegna. Rivista Italiana di Paleontologia 44: 107-126.

Millay M. 1979. - Studies of Paleozoic Marattialeans: a monograph of the American species of Scolecopteris. Palaeontographica B 169: 1-69.

Millay M. A. 1997. - A review of permineralized Euramerican Carboniferous tree ferns. Review of Palaeobotany and Palynology 95: 191-209.

Millay M. \& Galtier J. 1990. — Studies of Paleozoic Marattialean ferns: Scolecopteris globiforma n. sp. from the Stephanian of France. Review of Palaeobotany and Palynology 63: 163-171.

Peppers R. A. 1964. - Spores in strata of the Late Pennsylvanian cyclothems in the Illinois Basin. Geological Survey Bulletin 90, 89 p.

Pertusati P. C., Sarria E., Cherchi G. P., Carmignani L., Barca S., Benedetti M., Chighine G., Cincotti F., OgGiano G. (CON CONTRIbUti Di RONCHI A.). 2002. - Note illustrative della Carta Geologica d'Italia alla scala 1:50.000, Foglio 541 "Jerzu", Servizio Geologico d'Italia, $169 \mathrm{p}$.

Phillips T. L. \& Galtier J. in press. - Evolutionary and ecological perspectives of Late Paleozoic ferns Part II. The genus Ankyropteris and the Tedeleaceae. Review of Palaeobotany and Palynology.

Phillips T. L., Kunz A. B., Mickish D. J. 1977. Paleobotany of permineralized peat (coal balls) from the Herrin (No. 6) Coal member of the Illinois Basin, in GIVEN P. N. \& COHEN A. D. (eds), Interdisciplinary studies of Peat and Coal origins. Geological Society of America, Microfilm Publication 7: 18-49.

Pigg K. B., Taylor T. N. \& Stockey R. A. 1987. Paleozoic seed ferns: Heterangium kentuckiensis sp. nov., from the Upper Carboniferous of North America. Amer. J. Bot. 74: 1184-1204.

Pittau P. \& Del Rio M. 2002. — Palynofloral biostratigraphy of the Permian and Triassic sequences of Sardinia. Rendiconti della Societa di Paleontologia Italiana 1: 93-109.

Pittau P., Del Rio M. \& Funedda A. 2008. — Relationships between plant communities caracterization and basin formation in the Carboniferous-Permian of Sardinia. Italian Journal of Geoscience 127 (3): 637-653.

RENAULT B. 1869. - Étude de quelques végétaux silicifiés des environs d'Autun. Annales des Sciences naturelles, Se série (Botanique) 12: 161-190.

RENAULT B. 1876. - Recherches sur les fructifications de quelques végétaux provenant des gisements silicifiés d'Autun et de Saint-Étienne. Annales des Sciences naturelles, Ge série (Botanique) 3: 1-29.

RENAULT B. 1879. - Structure comparée de quelques tiges de la flore Carbonifère, Nouvelles Archives du Muséum d'Histoire Naturelle 2: 213-348.

RENAULT B. 1893-1896. - Bassin houiller et permien d'Autun et d'Épinac. IV. Flore fossile: Atlas (1893);
Texte (1896). Étude des Gites minéraux de la France. Imprimerie Nationale, Paris, 578 p.

RoNCHI A. 1997. - I prodotti sedimentari e vulcanici dei bacini permiani di Escalaplano e Perdasdefogu (Sardegna sudorientale): stratigrafia e loro inquadramento nell'evoluzione tardo-paleozoica del settore sudeuropeo. $\mathrm{PhD}$ Thesis, Università di Parma, $250 \mathrm{p}$.

Ronchi A., Sarria E. \& Broutin J. 2008. - The "Autuniano Sardo": basic features for a correlation through the Western Mediterranean and Paleoeurope Italian Journal of Geoscience 127 (3): 655-681.

Ronchi A., Broutin J., Diez J.-B., FreYtet P., Galtier J. \& Lethiers F. 1998. - New paleontological discoveries in some Early Permian sequences of Sardinia. Biostratigraphic and paleogeographic implications: Compte rendus de l'Académie des Sciences de Paris (Earth \& Planetary Sciences) 327: 713-719.

Ronchi A. \& FALORNI P. 2004. - Formazione di Rio su Luda. Carta Geologica d'Italia scala 1:50.000. Catalogo delle Formazioni, Unità validate (a cura della Commissione Italiana di Stratigrafica). Quaderni serie III. 7 (fasc. V): 155-159.

Roscher M. \& Schneider J. W. 2006. - PermoCarboniferous climate: Early Pennsylvanian to Late Permian climate development of central Europe in a regional and global context, in LUCAS S. G., CASSINIS G. \& SCHneIder J. W. (eds), Non-Marine Permian Biostratigraphy and Biochronology. Geological Society, London, Special Publications 265: 95-136.

RösSLER R. 2006. - Two remarkable Permian petrified forests: correlation, comparison and significance, in LUCAS S. G., CASSINIS G. \& SCHENIDER J. W. (eds), Non-marine Permian biostratigraphy and biochronology. Geological Society, London, Special Publications 265: 39-63.

SARRIA E. 1987. - Ricerche nel bacino antracitifero di Perdasdefogu, in "Progetto di ricerca Antracite, Sardegna centrale", Progemisa SpA, rel. int., 90 p.

SCHNeIDER J., KÖRner F., Roscher M. \& Kroner U. 2006. - Permian climate development in the northern peri-Tethys area: the Lodève Basin, French Massif Central, compared in a European and global context. Palaeogeography, Palaeoclimatology, Palaeoecology 240: 161-183.

ScotT D. H. 1932. - On a Scolecopteris (S. oliveri sp.n.) from the Permo-Carboniferous of Autun. I. The fructification. Journal of the Linnean Society of London (Botany) 49: 1-12.

Scott D. H. \& Holden H. S. 1933. - On Scolecopteris oliveri. Part II. The vegetative organs. J. Linn. Soc. London (Bot.) 49: 309-321.

STENZEL G. 1889. — Die Gattung Tubicaulis Cotta. Mitteilungen aus dem Koeniglichen Mineralogisch-Geologischen und Prehistorischen Museum in Dresden 8: 1-50.

Virgili C., CASsinis G. \& Broutin J. 2006. — Permian to Triassic sequences from selected continental areas 
of southwestern Europe, in LUCAS S.G., CASSINIS G. \& SCHNeider J. W. (eds), Non-marine Permian biostratigraphy and biochronology. Geological Society, London, Special Publications 265: 231-259.

WERNEBURG R., RONCHI A. \& SCHNEIDER J. W. 2007.The Early Permian Branchiosaurids (Amphibia) of Sardinia (Italy): systematic palaeontology, palaeoecology, biostratigraphy and palaeobiogeographic problems. Palaeogeography, Palaeoclimatology, Palaeoecology 252: 383-404.
ZeNKeR F. C. 1837. - Scolecopteris elegans Zenk. Ein neues fossiles Farngewächs mit Fructificationen. Linneaea 11: 509-512.

Ziegler P. A. \& Stampfli G. M. 2001. — Late Palaeozoic-Early Mesozoic plate boundary reorganization: collapse of the Variscan orogen and opening of Neotethys, in Cassinis G. (ed.), Permian continental deposits of Europe and other areas. Regional reports and correlations. Natura Bresciana, Museo Civico di Scienze Naturali, Monografia no. 25: 17-34.

Submitted on 5 March 2010; accepted on 10 November 2010. 